\title{
Algeria: 2009 Article IV Consultation-Staff Report; and Public Information Notice
}

In the context of the 2009 Article IV Consultation, the following documents have been released and are included in this package:

- $\quad$ The Staff Report for the 2009 Article IV Consultation, prepared by a staff team of the IMF, following discussions that ended on November 4, 2009, with the officials of Algeria on economic developments and policies. Based on information available at the time of these discussions, the staff report was completed on December 22, 2009. The views expressed in the staff report are those of the staff team and do not necessarily reflect the views of the Executive Board of the IMF.

- $\quad$ A Public Information Notice.

The policy of publication of staff reports and other documents allows for the deletion of market-sensitive information.

Copies of this report are available to the public from

International Monetary Fund • Publication Services

$70019^{\text {th }}$ Street, N.W. • Washington, D.C. 20431

Telephone: (202) 623-7430 • Telefax: (202) 623-7201

E-mail: publications@imf.org Internet: http://www.imf.org

\section{International Monetary Fund Washington, D.C.}




\title{
INTERNATIONAL MONETARY FUND
}

\author{
ALGERIA \\ Staff Report for the 2009 Article IV Consultation \\ Prepared by the Staff Representatives for the 2009 Consultation with Algeria \\ Approved by Amor Tahari and David Marston
}

December 16, 2009

- The 2009 Article IV consultation discussions took place in Algiers during October 21-November 4, 2009. The staff team consisted of Messrs. Toujas-Bernaté (head), Gijon, and De Bock, and Ms. Simard (all MCD).

- The mission met with Messrs. Djoudi (Minister of Finance) and Laksaci (Governor of the Bank of Algeria), other government officials, and representatives of the financial sector, trade unions and business associations. Mr. Maherzi, Advisor to the Executive Director for Algeria, participated in the discussions. The mission issued a statement, held a press conference, and participated in a live radio talk show.

- Over recent years, the Fund and the authorities have focused, in the context of surveillance, on macroeconomic policies to sustain growth while safeguarding stability; and structural reforms aimed at promoting private sector activity. This year, discussions also covered strategies to diversify the economy.

- Algeria's exchange rate is managed in a discretionary manner, and the regime is classified as "other managed". Algeria accepted the obligations of Article VIII, sections 2(a), 3, and 4, in 1997.

- Data provision to the Fund is broadly adequate for surveillance, despite shortcomings particularly in government finance statistics.

- It is proposed that the next Article IV consultation with Algeria take place on a standard 12-month cycle. 


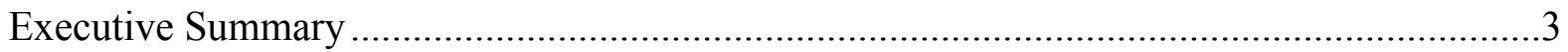

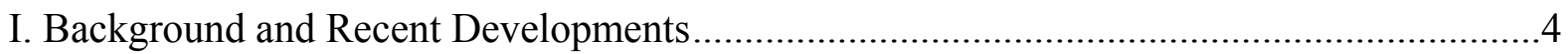

A. An oil-Dependent Economy Financially Sound but Facing

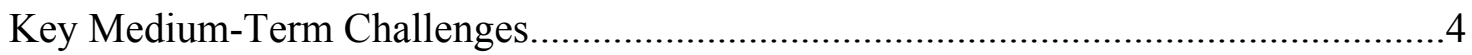

B. Nonhydrocarbon Growth Has Been Solid but Lower Hydrocarbon

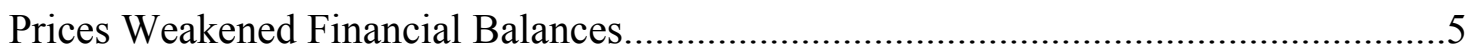

II. International Environment, Outlook and Risks............................................................

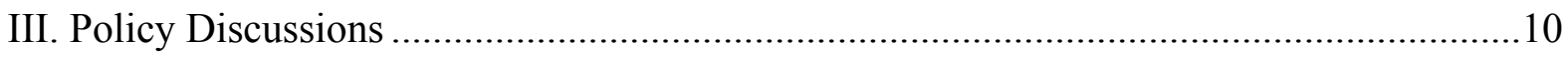

A. Fiscal policy Needs to be Redirected to Ensure Long-Term Sustainability.............10

B. Prudent Monetary Policy Should Continue to Sterilize Liquidity .....................................14

C. More Effective Intermediation Requires More Ambitious Reform .................................17

D. Slow Progress in Structural Reforms Will Weigh on Future Growth...............................19

\section{Boxes}

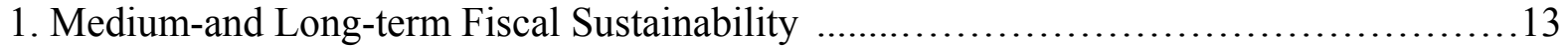

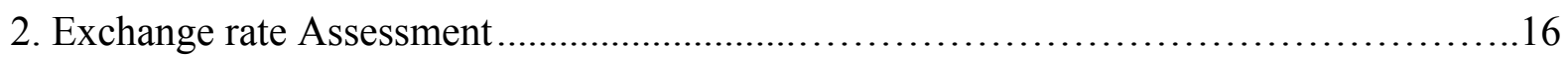

3. Relevant Measures Adopted by the 2009 Supplementary Budget Law (2009 SBL) ..........20

Figures

Panel A. Scenarios with Current Policies Under Alternative Oil Prices ....................................

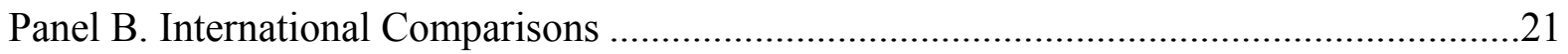

Tables

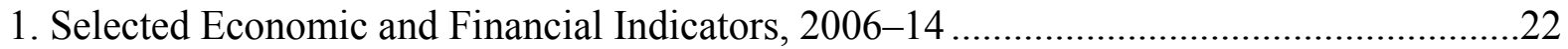

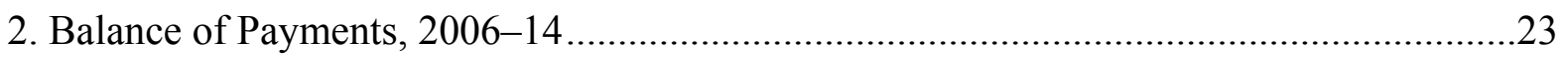

3. Summary of Central Government Operations, 2006-14 ..............................................24

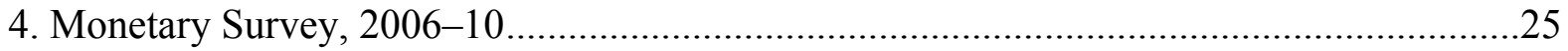




\section{EXECUTIVE SUMMARY}

Algeria has enjoyed several years of strong economic performance driven by public spending and was in a relatively sound position to face the global slowdown.

Nonhydrocarbon $(\mathrm{NH})$ growth has been robust, inflation low and the government has accumulated large savings in the oil stabilization fund (FRR) to finance a sizeable public infrastructure program (PIP). However, the fall of global demand for hydrocarbons has exposed Algeria's vulnerabilities. Despite the recent recovery of oil prices and the improvement of medium-term financial perspectives, the economy remains too dependent on hydrocarbon exports, unemployment is still relatively high, and productivity and the business climate lag behind main trading partners. NH growth and job creation are largely sustained by public spending, highlighting the pressing need to accelerate structural reforms to diversify the economy and let a competitive and outward-oriented private sector emerge.

\section{Key Issues and Policy Discussions}

The authorities intend to maintain the current fiscal stance to support the PIP, drawing on the amply sufficient FRR reserves. Staff supports this stance in the short run, but advises a swift return to medium-term sustainability to maintain fiscal space in case of adverse shocks on hydrocarbon demand and prices.

The authorities intend to pursue fiscal reform to increase efficiency of public spending and NH revenues. Staff supports sustained implementation of these reforms, particularly as they should enhance quality and efficiency of public spending, and ensure high infrastructure content. Staff also warns against undermining advances in revenue administration by excessive proliferation of tax incentives.

Algeria has successfully absorbed excess liquidity from the oil revenues and the PIP but staff encourages the adoption of new instruments to improve liquidity monitoring and management. Staff also suggests increasing policy rates back to their levels of March 2009 to control potential inflationary pressures.

Algeria's policies have been consistent with external stability. Staff estimates concur with the central bank's analysis that the real exchange rate of the dinar is near its equilibrium level.

Successful economic diversification based on sustained NH growth requires continued macroeconomic stability as well as better infrastructure, human capital, and public services. Structural reforms have been timid and need to be accelerated to promote private sector development, and improve financial intermediation, business climate, and further integration in the regional and world economies. The new rules limiting stakeholding and financing of foreign direct investment and the slow pace of regional and multilateral trade negotiations could hamper Algeria's effort to ensure a sustainable export-oriented diversified growth. 


\section{BACKGROUND AND RECENT DEVELOPMENTS}

\section{A. An Oil-Dependent Economy Financially Sound But Facing Key Medium-Term Challenges}

1. The political situation has been stable, with President Bouteflika elected for a third term in April 2009, but AlQaeda in the Maghreb continues to pose a threat.

2. Following several years of strong economic performance and prudent macroeconomic management when oil prices were high, Algeria has faced the current global slowdown from a position of relative strength. Over the last decade, annual overall and nonhydrocarbon (NH) GDP growth averaged respectively close to 4 percent and 5 percent, largely driven by public spending, and inflation was subdued at around 3 percent. A good share of the hydrocarbon export revenues was saved in reserves and in the oil stabilization fund, or used to drastically reduce external and public debt. ${ }^{1}$

3. The key challenge is to adopt appropriate policies to ensure long-term macroeconomic stability and promote economic diversification. Although Algeria has been insulated from direct financial contagion, the steep fluctuations in hydrocarbon prices and the slowdown of global energy demand have reexposed Algeria's vulnerabilities. While having

\footnotetext{
${ }^{1}$ Given that external and domestic public debts are very low and unlikely to rise significantly under plausible scenarios; this report does not include a debt sustainability analysis.
}

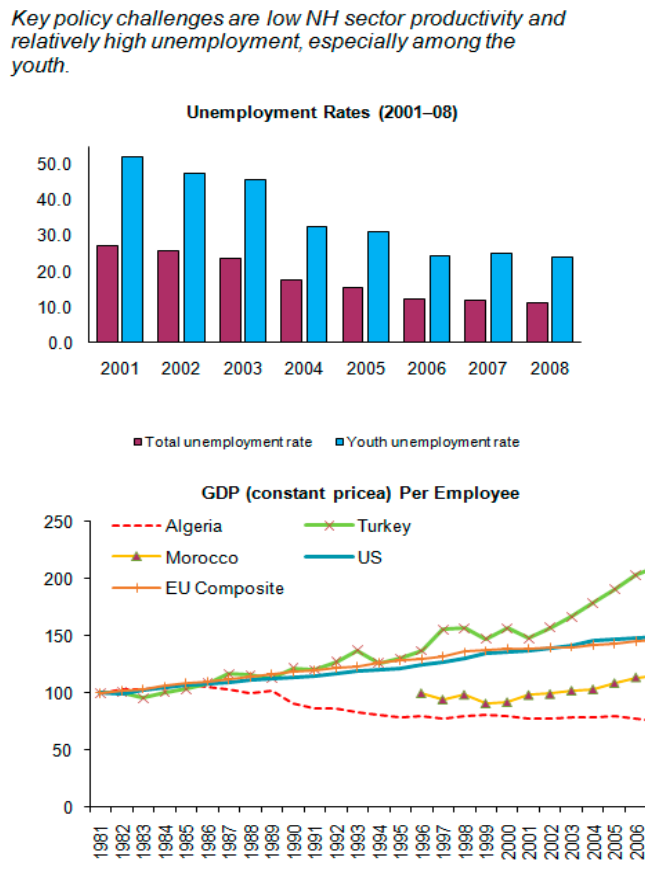

Source: Algerian authorities; and IMF staff estimates.

fallen, youth unemployment remains high (24 percent), and Algeria is still too dependent on the hydrocarbon sector, with an inward-oriented $\mathrm{NH}$ sector sustained by public spending. Moving away from overreliance on hydrocarbon revenues and enhancing job creation require speeding up reforms promoting productivity gains and private investment. Key areas in the Fund's surveillance mandate include the financial sector, tax policy and revenue administration, and further integration in the regional and global economies. 


\section{B. Nonhydrocarbon Growth Has Been Solid But Lower Hydrocarbon Prices Weakened Financial Balances}

The Algerian economy grew at healthy rates due to high hydrocarbon revenues...

Real GDP Growth (in percent, 2005-09)

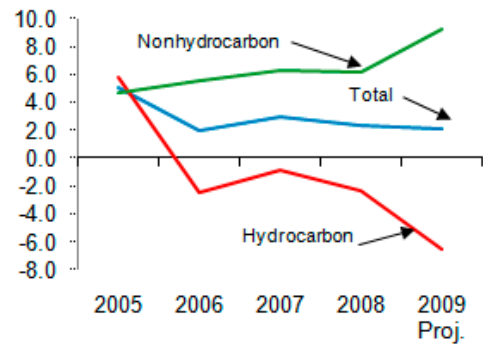

...generating large $C A$ surpluses and significant accumulation of reserves.

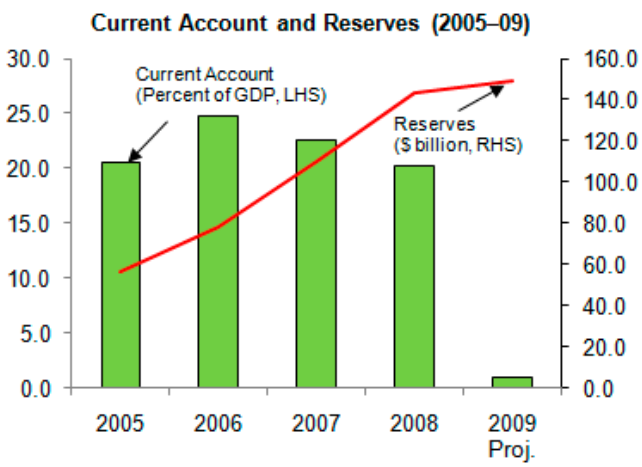

Inflation increased slightly in the second half of 2009 due to fresh food products. Non-fresh food inflation declined

Price Increases (y/y) (Jan 2003-Aug 2009)

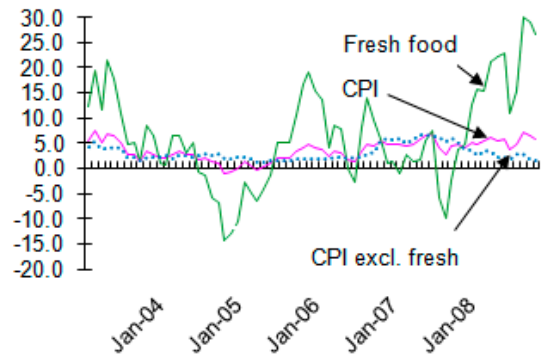

Source: Algerian authorities; and IMF staff estimates
4. With lower hydrocarbon revenues, external and fiscal balances deteriorated, but economic growth continues to be strong, with low inflation, sizable reserves and minimal external debt.

- $\quad$ NHGDP growth reached 6.1 percent in 2008, mainly driven by the PIP. Higher NH growth is expected in 2009 (possibly above 9 percent), reflecting an excellent cereal harvest and the continued strength of PIP-led service and construction sectors. Hydrocarbon production will decline further this year (by 6-7 percent) due to lower global demand, bringing overall growth down to about 2 percent.

- $\quad$ Headline inflation reached 5.8 percent (y-o-y) in September 2009 due to a 25 percent surge in fresh food prices, reportedly caused by structural shortcomings in the supply chain. However, excluding fresh food, inflation declined further to 1.4 percent, reflecting (a) an effective liquidity absorption policy by the Bank of Algeria (BA); (b) administered prices for food staples and constant domestic energy prices since 2004; and (c) high import content of domestic demand.

- $\quad$ The fall in world hydrocarbon prices weighed on the external position but external reserves remain large. The current account surplus is projected to decline from 20 percent of GDP in 2008 to 1 percent in 2009, reflecting the drop in hydrocarbon exports (10 percent in volume relative to 2008) and the surging PIP-related imports. With a small current account surplus and net capital inflows, official reserves have grown by $\$ 3$ billion since end-2008, reaching \$146 billion at end- 
In 2009 Algeria will record the first fiscal deficit since 1999

Overall and Nonhydrocarbon Fiscal Balances, 2004-09

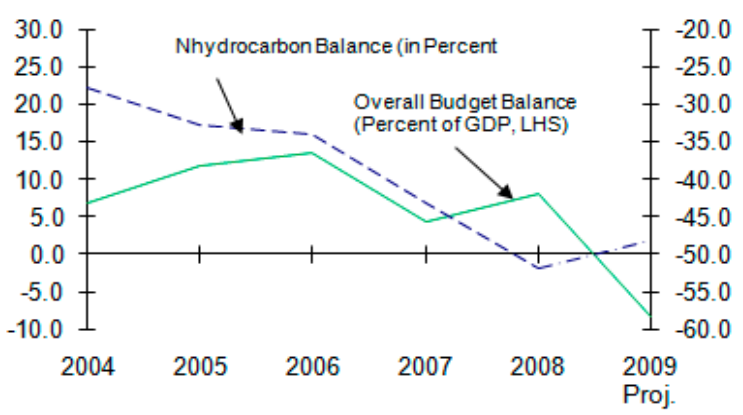

Credit growth has been robust and Algerian banks remain liquid.

Financial sector (Jan. 2008-June 2009)

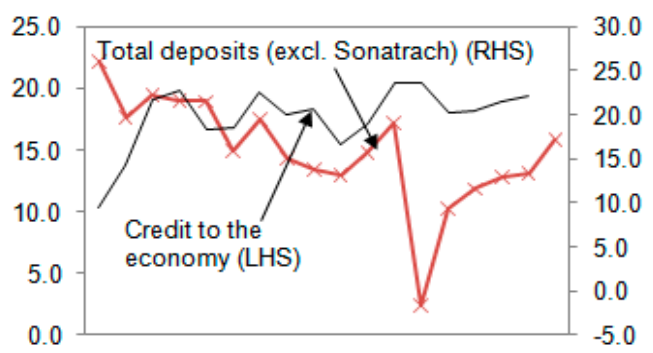

Nominal and real effective exchange rates have depreciated since early 2008

Exchange Rates, Jan. 06-Aug. 2009

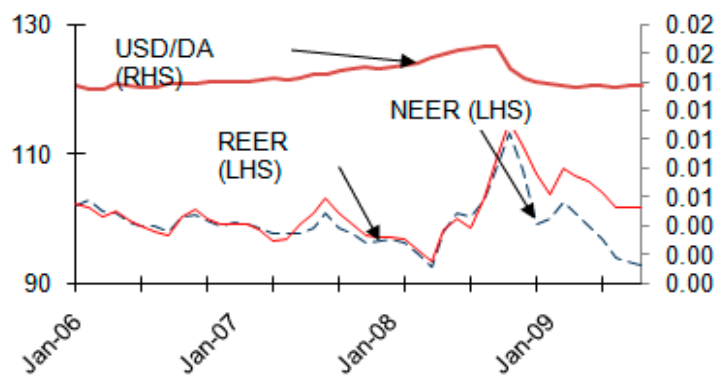

Source: Algerian authorities; and IMF staff estimates.
September 2009 (3 years of imports). ${ }^{2}$

- $\quad$ The overall fiscal position is greatly affected by the fall in hydrocarbon revenues, but the $\mathrm{NH}$ balance should improve. In 2009, Algeria will post its first overall fiscal deficit in a decade, at 8 percent of GDP, following a surplus of 8 percent in 2008. It should be largely financed with domestic nonbank resources, leaving the savings in the oil stabilization fund (FRR) at around 40 percent of GDP. The strong growth in NH revenues (by 20 percent), reflecting the further modernization of the revenue administration and higher income tax collections linked to the 2008 wage increase, will partly offset the fall in hydrocarbon revenues. Current expenditure would grow by 15 percent in 2009 due to additional maintenance costs of new infrastructure and employment support programs, while capital expenditures would remain constant in real terms after several years of significant growth.

Consequently, the NH fiscal deficit will decline from 52 percent of NHGDP in 2008 to 48 percent in 2009, stabilizing the sharp deterioration observed since 2004.

- $\quad$ Growth in deposits and credit is robust, with the latter averaging 19 percent (y-o-y) in June 2009. The BA has been absorbing the growing abundant liquidity generated by the PIP and SONATRACH (the state hydrocarbon company) revenues. At the same time, it also reduced its uptake rates in March 2009 to support domestic demand.

- $\quad$ The nominal and real effective exchange rates depreciated on average by 7.7 percent and 5 percent, respectively, during January-September 2009 from the same period last year, reflecting changes in fundamentals such as the terms of trade and inflation differentials with major trading partners.

\footnotetext{
${ }^{2}$ In addition, the SDR allocation (SDR 0.9 billion) further increased BA's net international reserves.
} 


\section{INTERNATIONAL ENVIRONMENT, OUTLOOK AND RISKS}

5. In the short term, growth will continue to be sustained by large public spending. Despite an expected fall in agricultural production, NHGDP could grow by $5 \frac{1}{2}$ percent in 2010 pulled by the continuing PIP and the acceleration of SONATRACH's investment program. Output in the hydrocarbon sector should improve with the international economic recovery, contributing positively to overall growth for the first time in many years. Therefore, real GDP growth could reach around $4 \frac{1}{2}$ percent in 2010. Inflation should come below 5 percent if fresh food prices stabilize.

\section{Higher international oil prices} projected in the WEO $(\$ 76 /$ bbl in 2010) should improve the external and fiscal balances. The current account surplus would increase to 4 percent of GPD in 2010 and import coverage by international reserves should rise. The fiscal deficit could be near $6 \frac{1}{2}$ percent of GDP in 2010, as expenditure would remain high.

\section{The medium-term outlook} remains favorable despite the possible slowdown of $\mathrm{NH}$ growth due to stabilized public expenditures. A
5 percent NHGDP growth rate would be supported by a new PIP planned for to stabilized public expenditures. A 5 percent NHGDP growth rate would be supported by a new PIP planned for 2010-14 for a total announced amount of US\$150 billion and SONATRACH's investments. The latter should increase hydrocarbon production (mostly natural gas) in the medium term and contribute to a 2 percent hydrocarbon growth.

\section{The medium-term outlook has} improved substantially with the recovery of oil prices but remains very sensitive to their future levels. If capital expenditures are maintained at their current nominal level, staff's baseline scenario shows that Algeria will remain in a relatively sound financial position, with FRR resources declining but still above 20 percent of GDP in 2014. International reserves would be around 4 years of imports of goods and services in 2014. However, government net assets (FRR minus public debt) would decrease significantly from $31 \frac{1}{2}$ percent of GDP in 2008 to 4 percent in 2014.

Baseline scenario

\begin{tabular}{|c|c|c|c|c|c|c|c|}
\hline Base scenario & 2008 & 2009 & 2010 & 2011 & 2012 & 2013 & 2014 \\
\hline International oil price (US\$/bbl) & 99.0 & 61.5 & 76.5 & 79.5 & 81.0 & 83.0 & 84.8 \\
\hline Overal budget balance (percent of GDP) & 8.1 & -8.4 & -6.6 & -5.4 & -3.9 & -2.4 & -1.4 \\
\hline FRR (percent of GDP) & 38.8 & 39.2 & 31.5 & 26.5 & 23.0 & 21.2 & 20.2 \\
\hline Reserves (US\$ billion) & 143.1 & 149.1 & 157.2 & 168.3 & 181.7 & 197.4 & 215.4 \\
\hline Primary budget deficit (percent of NHGDP) & -51.9 & -48.0 & -47.0 & -44.7 & -41.3 & -38.0 & -35.3 \\
\hline Current account balance (percent of GDP) & 20.1 & 0.9 & 3.9 & 5.3 & 6.2 & 7.0 & 7.7 \\
\hline Government net assets (percent of GDP) $\left(^{*}\right)$ & 31.4 & 25.7 & 17.1 & 11.1 & 7.2 & 5.0 & 4.1 \\
\hline
\end{tabular}

Source: Algerian authorities; and staff estimates and projections. 


\section{A worsening world economy and a}

\section{significant decline in energy prices would}

present downside risks. Under a scenario

with oil prices at $\$ 45 / \mathrm{bbl}$ (near the average

Oil has been key in Algeria and medium term sustainability rests on oil price outlook

price in the first half of 2009) until 2014, current policies would be difficult to maintain as the $\mathrm{FRR}^{3}$ would not be sufficient to finance the budget deficit and public debt would have to increase significantly (Panel A). The fiscal adjustment needed to avoid such an outcome would include scaling down the PIP, implying slower NH growth and higher unemployment.

\section{Public spending alone cannot} Real Oil Prices, $1970-14$ (in 2008 US\$) $1 /$
1/Average oil price deflated by US CPI

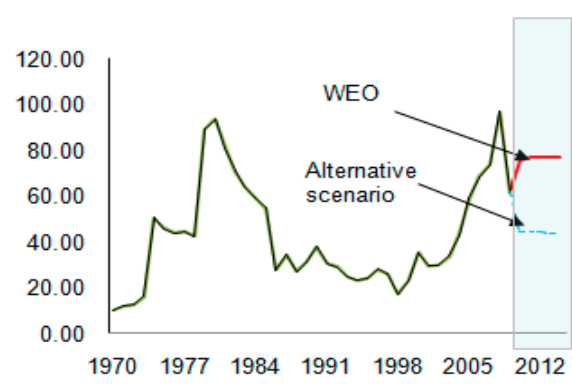

Source: Algerian authorities; and IMF staff estimates

ensure long-term growth and the outlook rests on decisive actions to promote private sector development and economic diversification. NHGDP growth would be lower without substantial improvements in productivity and business climate, needed to elicit a strong private sector supply response.

\section{Staff appraisal:}

The imbalances caused by the fall in oil prices show that Algeria continues to face important challenges. Although the medium-term financial outlook improved with the recovery of oil prices, it remains highly vulnerable to their volatility. Under an alternative scenario with lower oil prices, avoiding a significant increase in public debt would require a stronger fiscal adjustment. Moreover, NH private sector is mainly inward oriented, and productivity and business climate are lagging compared to trading partners. Public sector alone cannot sustain growth over the long-term, and major productivity gains are necessary to reduce the relatively high unemployment. This can only be achieved through continued macroeconomic stability, and better infrastructure, human capital, and public services.

\footnotetext{
${ }^{3}$ According to its legal requirements, FRR resources should be kept above 740 billion DA, which would result in higher levels of public debt to finance public deficits.
} 
Panel A: Scenarios With Current Policies Under Alternative Oil Prices
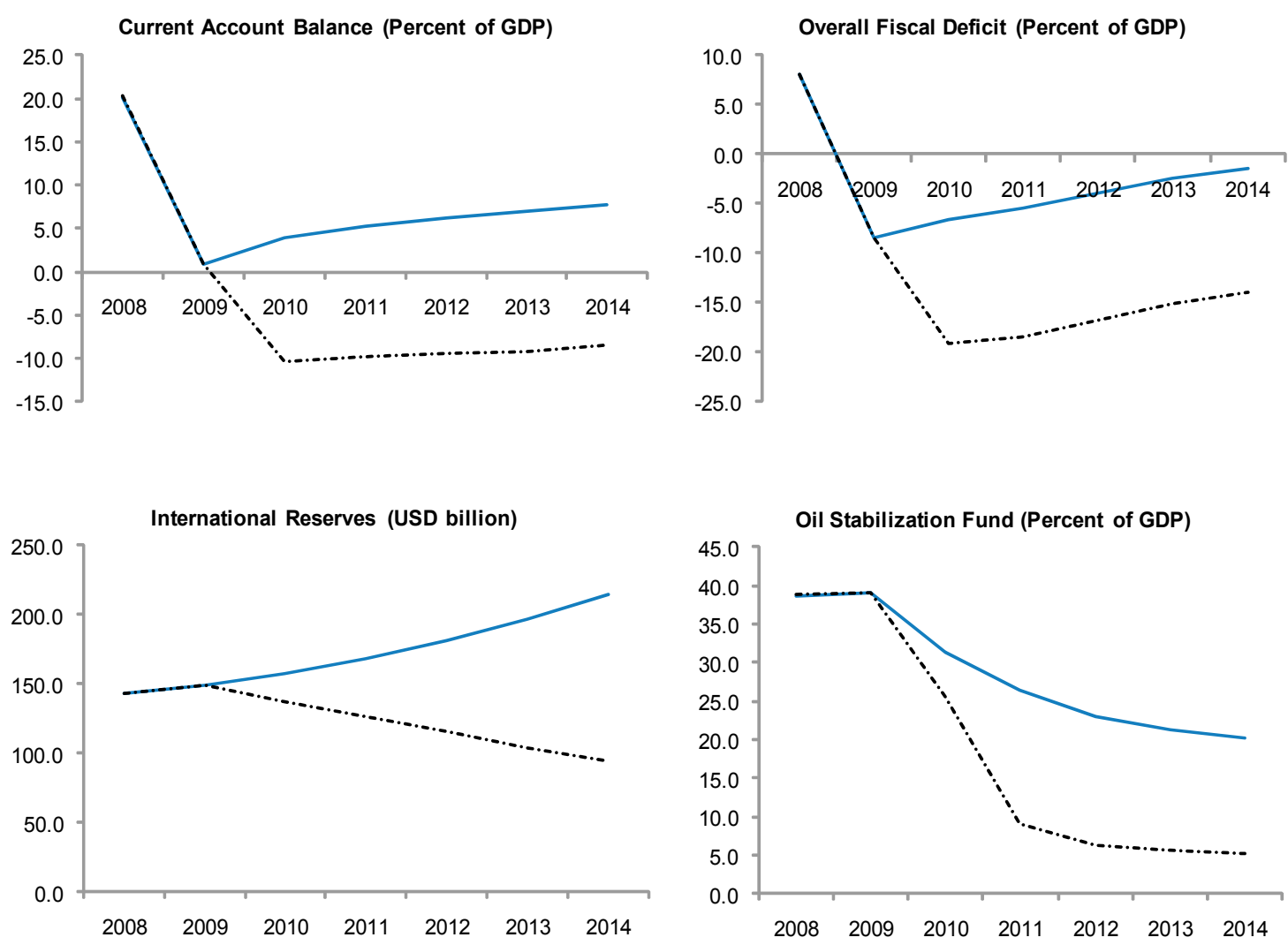

_ Baseline scenario (WEO oil price projections)

.... Alternative scenario (oil price at $\$ 45 / \mathrm{bbl}$ )

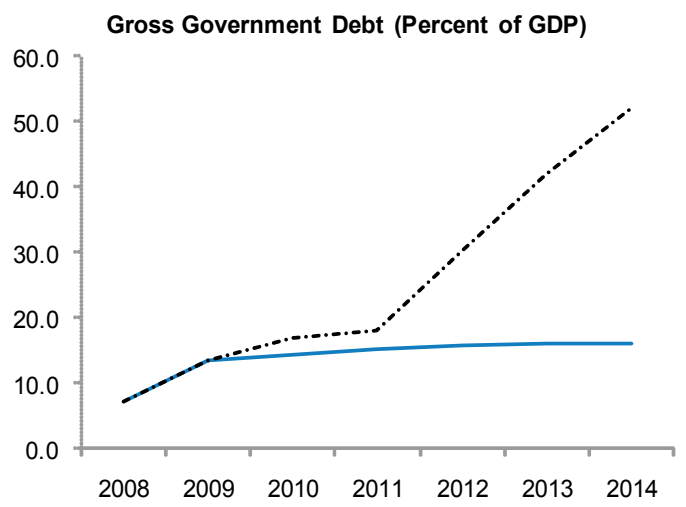

Source: Algerian authorities; and IMF staff estimates and projections. 


\section{Policy Discussions}

11. Discussions focused on policies to diversify the economy, raise NHGDP growth, and restore medium-term fiscal sustainability.

\section{A. Fiscal Policy Needs to be Redirected to Ensure Long-Term Sustainability}

\section{Background and staff analysis}

High hydrocarbon prices allowed Algeria to accumulate large resources in the oil stabilization fund

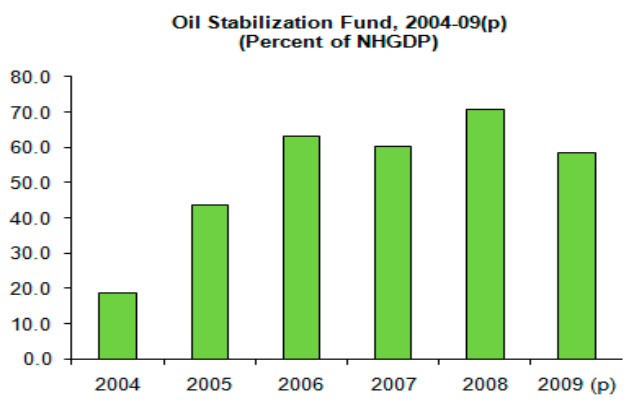

and finance increasing expenditure

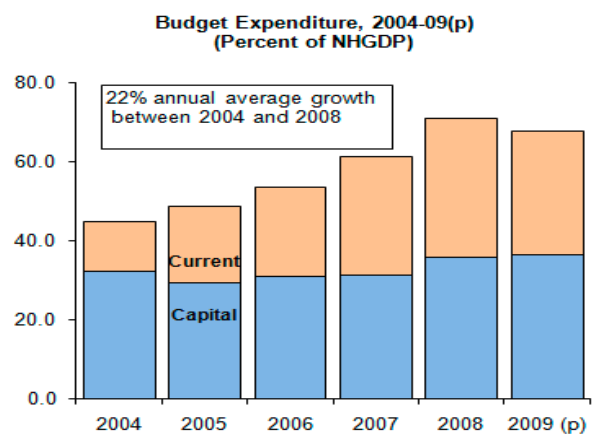

Hydrocarbon resources also allowed to pay back public and external debt

Government and External Debt, 2004-09 (p)

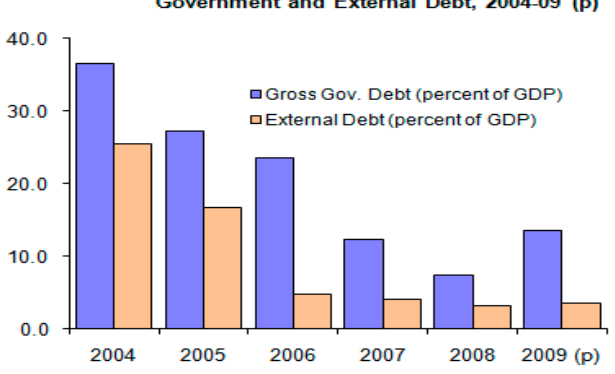

Source: Algerian authorities; and IMF staff estimates

\section{The sizable resources} accumulated in the $\mathrm{FRR}^{4}$ provide latitude in the conduct of fiscal policy in the short term and will allow continued implementation of the PIP. Enhancing the vitality and growth potential of the $\mathrm{NH}$ sector hinges on continued implementation of a well-targeted program of expanding and maintaining public infrastructure, and on supporting small and medium-sized private enterprises. Following a sharp expansion in capital expenditure between 2005-08 equivalent to 23 percent of NHGDP, the 2010 draft budget law provides for still large but slightly decreasing public investment. With additional hiring of civil servants and higher maintenance costs, current expenditures are projected to increase by 14 percent in 2010 .

13. However, fiscal policy should be redirected towards a long-term sustainable path to maintain fiscal space in case of adverse scenarios. Given finite hydrocarbon resources, fiscal policy can be gauged against rules derived from the permanent income framework that would

\footnotetext{
${ }^{4}$ The following links provide a detailed presentation of FFR and SONATRACH's financial situation, http://www.dgpp.mf.gov.dz/index.php?option=com c c ontent\&view $=$ article\&id $=78$ for the FRR and http://www.sonatrach-dz.com/rapport-financier.htm for SONATRACH
} 
ensure the availability of these resources over a very long term (Box 1). For instance, the recent significant expansion in expenditure brought the NH primary deficit above its benchmark under the more stringent rule of constant real wealth per capita by about 12 percentage points of NHGDP in 2009. This type of analysis, together with fiscal projections under an alternative scenario with lower oil prices, supports the gradual but significant fiscal adjustment projected over the medium term, anchored on:

- Rationalizing of expenditure through improved targeting and controls. Since 2004, current expenditures have been increasingly dependent on hydrocarbon revenue and are expected to further rise with the maintenance of new infrastructure. Expenditures would benefit from an overhaul, since current spending is difficult to compress when hydrocarbon revenues drop significantly, and capital expenditures have historically been subject to systematic cost overruns. To that end, the growth in the wage bill should be contained and the targeting of all subsidies and transfers be reassessed, while the issue of investment cost overruns should be addressed by the March 2009 decree reinforcing financial controls on public spending.
- Continued improvement in NH tax collection. Several steps were taken this year to that end, such as making clean tax records a prerequisite for bank transactions and simplifying revenue administration. The draft 2010 budget law also provides for further efficiency improvements in revenue collection, which should further increase the budget share of $\mathrm{NH}$ revenue over the medium term. However, the growing number of tax exemptions requires enhanced controls which divert human resources away from revenue collection and undermines efforts to streamline the tax system.

14. Improving fiscal management and budget systems should help enhancing the quality and effectiveness of expenditure. Ongoing reforms, with World Bank assistance since 2005, aim at assessing the medium-term impact of the PIP on current spending, developing tools to evaluate program performance, and better controlling spending. These reforms should be actively pursued, to achieve in particular the full implementation of the medium-term budget programming system by end-2012 as planned. It would also be desirable to better assess and reduce medium-term fiscal risks linked to eventual contract renegotiations of Public-Private Partnerships (PPP).

\section{Authorities' views and policy intentions}

\section{The authorities intend to} maintain the current fiscal stance in 2010 to sustain aggregate demand and enhance growth potential. Low public debt and high savings in the FRR provide sufficient leeway. The authorities plan to support private consumption through hiring additional civil servants and raising scholarships, and to stimulate private investment-including in infant industries competing with imports-by extending tax incentives. The current PIP will be implemented as planned. Priorities and composition of the new PIP for 2010-14 are under preparation. 


\section{The authorities remain} committed to preserving long-term fiscal sustainability. They noted the projected decline in the $\mathrm{NH}$ deficit in 2009-10. After completing the broad civil service reform, future wage increases should be linked to productivity and economic performance, in line with the National and Social Pact. Work is ongoing to streamline subsidies, but these are also guided by political and economic efficiency considerations. Execution of the current and future PIPs will be prioritized and based on the fiscal outlook. Tax and customs administration reforms, already credited with an increased $\mathrm{NH}$ revenue performance, will be pursued actively for additional revenue gains in the medium term. Meanwhile, granting of tax incentives to stimulate $\mathrm{NH}$ growth will continue while monitoring their impact on revenue administration.

\section{The authorities attach high} importance to the quality and efficiency of public spending. The projects evaluating agency (Caisse Nationale d'Équipements et de Développement, $C N E D)$ is now fully operational, but will stay focused on large non-PPP projects. Reform of budget management is progressing, in particular to establish a medium-term expenditure framework, and the role of financial comptrollers was broadened.

\section{Staff appraisal:}

Staff supports maintaining the current fiscal stance in 2010 but encourages the authorities to swiftly return to a sustainable fiscal path once global recovery takes hold. Continued implementation of the infrastructure component of the PIP and support to the SMEs is desirable and the sizable savings accumulated in the FRR can be used to that effect. Nonetheless, a thorough overhaul of the current and capital spending would free up budgetary resources, better preserve hydrocarbon wealth in the medium-term and maintain fiscal space in case of adverse shock on oil prices. Current expenditure, in particular the wage bill, should be firmly contained in the medium term to make room for additional maintenance costs related to the new infrastructure built with the PIP. Similarly, the authorities' ongoing advances to reform the revenue administration should boost NH revenue over the medium term, provided that growth in tax incentives is contained.

Given that public spending is key for the economy, ensuring its quality and efficiency is critical. The authorities' program to modernize budget systems will likely be very helpful in that respect. 


\section{Box 1. Medium-and Long-Term Fiscal Sustainability}

The high and growing dependence of Algeria's budget on hydrocarbon revenue is a significant vulnerability given volatile global prices and nonrenewable reserves. ${ }^{1}$

To ensure long-term fiscal sustainability with Algeria: share of hydrocarbon revenue in total budget revenue, some equalization of consumption across generations, hydrocarbon resources should be allocated to budget spending on a permanent income basis. ${ }^{2}$ Accordingly, real hydrocarbon wealth is preserved by substituting geological hydrocarbon assets by financial ones to preserve real wealth. The criterion selected for annual expenditure funded by hydrocarbon wealth (i.e. the NH primary deficit) may be, for instance, to maintain a constant real wealth or a constant real wealth 1991-2014 (in percent)

per capita over the medium term. The latter criterion is more restrictive for the initial years but implies that future generations would benefit more from the oil wealth than under the criterion based on constant total real wealth.

Precautionary considerations are likely to further reduce the $\mathrm{NH}$ primary deficit criterion. Future hydrocarbon revenues are highly uncertain, mainly because of large price fluctuations. Additional budgetary savings out of hydrocarbon resources are needed to cushion the budget against uncertainty. ${ }^{3}$ The required additional savings are lower when initial financial reserves are high.

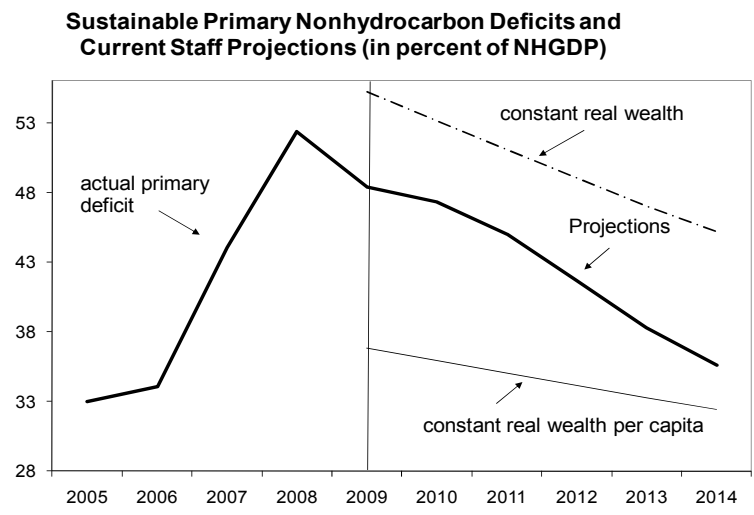

1/See BP Statistical Review of World Energy, June 2009, for estimates of proven reserves.

2/See IMF Country Report 05/52.

3/See IMF Working Paper WP/09/33. 


\section{B. Prudent Monetary Policy Should Continue to Sterilize Liquidity}

\section{Background and staff analysis}

Liquidity Absorption, Jul 07_Jul 09

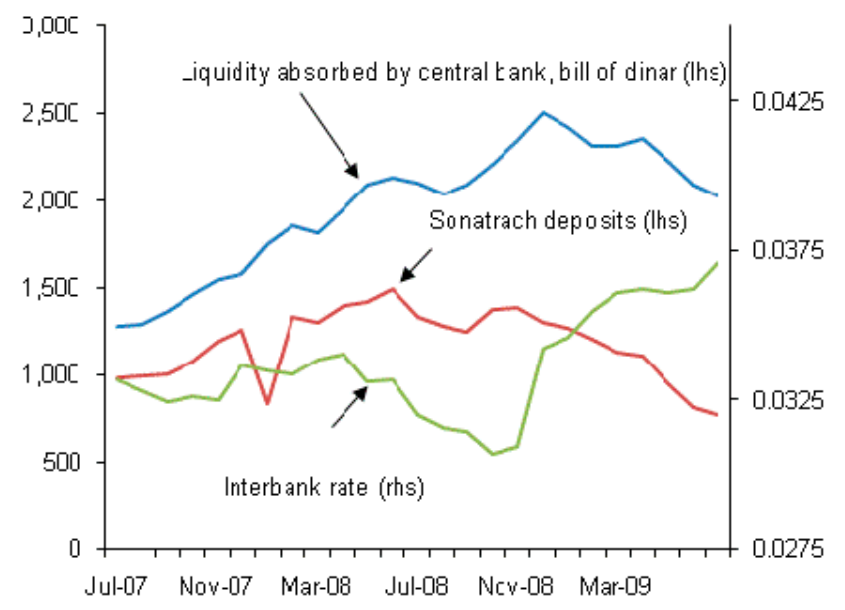

18. Revenues from hydrocarbon exports and fiscal policy have boosted liquidity in recent years, which should be adequately sterilized to fend off inflationary pressures. Whereas the growth in SONATRACH's deposits has slowed and even turned negative in the past year, the amount of nonSONATRACH liquidity absorbed by the central bank has grown significantly. The changing nature of the system's liquidity should be closely monitored. Forecasting could be improved by exchanging more information with the Ministry of Finance on government spending combined with an econometric analysis of liquidity needs. Moreover, abundant liquidity poses significant challenges for the transmission of monetary policy, particularly in the current context of higher domestic food prices, uncertain import prices and limited activity on the interbank market.

Furthermore, with still robust money and credit growth, the authorities could envisage increasing the policy interest rate back to its pre-cut level of March 2009, or higher if inflationary pressures were to materialize. To maximize the effects of its actions, the BA should clearly state its goals and instruments at each intervention.

19. The real effective exchange rate of the dinar has remained near its equilibrium level. The BA is the de-facto sole seller of foreign exchange and operates a managed float, whereby the nominal exchange rate is gradually adjusted towards a long-term real equilibrium target. Despite the strong volatility in Algeria's terms of trade, staff calculations suggest that the current level of the real effective exchange rate is in line with its fundamentals implied by the Equilibrium Real Exchange Rate and Macroeconomic Balance approach (Box 2).

\section{Authorities' Views and Policy Intentions}

20. The authorities stand ready to adjust monetary policy instruments based on their close monitoring of both excess liquidity and inflation underlying trends. They see overall inflation under control notwithstanding the sharp increase in fresh food prices. They consider their liquidity management effective, based on 
two short-term liquidity facilities, but were receptive to the suggestion of adding facilities with longer maturities. They are also considering the use of required reserves as an additional instrument for liquidity absorption, and would stand ready to include BA's refinancing rate in future potential policy moves if needed.
21. The authorities believe that the flexible exchange rate management has kept the dinar near its equilibrium level, consistent with their monetary policy objective and external stability. They noted that estimates of the equilibrium real exchange rate are inherently uncertain, and should be treated with caution.

\section{Staff appraisal:}

The BA has been able to contain inflationary pressures, but it could become a concern if liquidity continues to grow, and the authorities should stand ready to tighten monetary policy to regulate the excess liquidity. The rate cuts of early 2009 could be reversed to control potential inflationary pressures, and the refinancing rate included in future policy moves if a stronger signal is needed. Policy moves should be disseminated widely to strengthen their signaling effects. Staff encourages the authorities to refine their instruments for monitoring, assessing and absorbing the abundant liquidity.

The BA should continue to pursue an exchange rate policy consistent with external stability, and closely monitor developments to minimize the risk of misalignment. 


\section{Box 2. Exchange Rate Assessment}

Staff and authorities evaluated the level of the dinar implied by the Equilibrium Real Exchange Rate (ERER) and Macroeconomic Balance approach. ${ }^{1}$ Following IMF's CGER methodology but with the specific parameters for an oil producer like Algeria, the estimated coefficients and the WEO projected medium-term fundamental values were used to compute the equilibrium levels of the real effective exchange rate (REER) under the two methodologies. In both cases, the RER was found to be close to its equilibrium level at the projection horizon.

\section{Exchange Rate Misalignment}

(In percent)

\begin{tabular}{lcccccc}
\hline & \multicolumn{2}{c}{ EREER Approach } & MB Approach * & \multicolumn{2}{c}{ Average } \\
\cline { 2 - 3 } \cline { 5 - 7 } & 2009 & 2014 & & 2009 & 2014 \\
\hline 2009 Article IV update & -34 & 11 & -10 & -22 & 0 \\
\hline
\end{tabular}

"+": Overvaluation.

* The current account norm is a surplus of 5.5 percent of GDP.

The reduced form ERER specific to Algeria was reestimated based on the following explanatory variables;

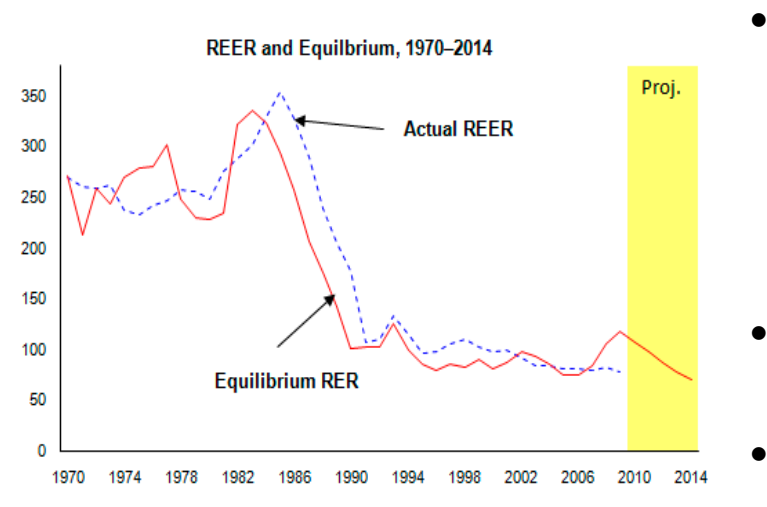

- $\quad$ Algeria's terms of trade for goods and services (ToT) from the WEO database. The model with the terms of trade as an explanatory variable generates a better statistical fit than the model with the real oil price and is more consistent with the ERER estimations of CGER.

- $\quad$ The differential of output per worker in Algeria vis-à-vis trade partners (prod).

Government spending as a percentage of GDP $(G)$.

A Vector Error Correction estimates the following equilibrium long-run cointegrating relationship (t-stats between parentheses):

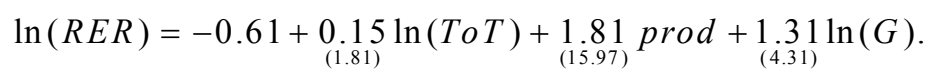

Based on this equation, the deviation between the equilibrium and actual real exchange rate estimated for 2009 would point to some current underlying inflationary pressures (in large part driven by the government expenditure expansion), which should subside in the future along with the projected gradual adjustment in government expenditure.

1/ For details, see IMF Country Report 08/104. 


\section{More Effective Intermediation Requires More Ambitious Reform}

\section{Background and staff analysis}

22. More effective financial intermediation would help channel Algeria's large savings to private sector investment, which remains low outside the oil sector. Despite the robust credit growth, intermediation levels are low by regional standards (see Panel B). The banking sector remains very liquid with relatively low lending due to high credit risks. The authorities took several measures to improve intermediation and develop the financial sector including: (a) increasing minimum capital requirement for banks and insurance companies; (b) raising banks limits to invest in participated businesses; and (c) promoting mortgage and loans to SMEs financing with government incentives. However, progress has been limited and the new consumer lending restrictions could negatively impact bank intermediation.

\section{Financial soundness indicators} have improved in 2008 but the level of nonperforming loans (NPLs) remains high. The loans requiring 100 percent provisioning fell from 22 percent in 2007 to 18 percent in 2008 , due to continued government's NPLs purchases plan for state-owned enterprises (SOEs). ${ }^{5}$

Nonetheless, the banking system does not pose short-term macroeconomic risk: it is adequately capitalized and profitable, has

\footnotetext{
${ }^{5}$ This plan is part of a program to restructure SOEs (see IMF Country Report No. 09/108)
}

satisfactory provisioning, and does not rely on foreign lending for market funding.

\begin{tabular}{|c|c|c|c|c|}
\hline \multicolumn{5}{|c|}{ Financial Soundness Indicators (in percent) } \\
\hline & 2005 & 2006 & 2007 & 2008 \\
\hline Capital adequacy ratio & 12 & 15 & 13 & 17 \\
\hline Public banks $1 /$ & 12 & 14 & 12 & 16 \\
\hline Foreign banks $2 /$ & 19 & 22 & 18 & 20 \\
\hline Classified loans/total loans & 36 & 35 & 36 & 28 \\
\hline NPLs/total loans $3 /$ & 19 & 18 & 22 & 18 \\
\hline Public banks & 20 & 19 & 24 & 20 \\
\hline $\mathrm{o} / \mathrm{w}$, to private sector & 10 & 12 & 19 & 16 \\
\hline Foreign banks & 3 & 3 & 9 & 7 \\
\hline Other class./total loans 4/ & 17 & 17 & 13 & 10 \\
\hline Public banks & 18 & 18 & 15 & 11 \\
\hline Foreign banks & 2 & 6 & 2 & 2 \\
\hline Provisions/classified loans & 49 & 54 & 56 & 62 \\
\hline Public banks & 49 & 54 & 55 & 61 \\
\hline Foreign banks & 62 & 49 & 85 & 86 \\
\hline Return on equity & 8 & 19 & 25 & 25 \\
\hline Public banks & 6 & 17 & 24 & 25 \\
\hline Foreign banks & 25 & 23 & 28 & 26 \\
\hline
\end{tabular}

\section{Implementing the 2007 FSAP} Update recommendations should continue. Large public banks would benefit as they usually lack appropriate internal risk assessment systems which complicates lending, especially to SMEs and retail customers. Moreover, the possibility of privatizing public banks under appropriate market conditions could be explored again, to benefit from international experience and increase the efficiency of the banking sector. 


\section{Authorities' Views and Policy Intentions}

\section{The financial sector remains at} the core of the authorities' reform strategy. They are keenly aware that the financial sector needs upgrading to finance the economy's investment needs. They emphasized initiatives aimed at increasing the system's lending capacity, including additional government funding for increasing public banks capital and restructuring public enterprises. They noted that the high level of NPLs was largely related to old claims, and is being actively addressed through the government purchase plan of SOEs' loans. They estimated that thanks to that program, the overall ratio of classified loans was brought down to around 15 percent in June 2009.

\section{The authorities emphasized the steps achieved to improve intermediation and channel the high levels of savings toward private investment in the $\mathrm{NH}$ sector. They} considered that the measures taken to strengthen banks and other financial institutions such as insurance companies were the appropriate steps to reform the financial sector. Moreover, they intend to adopt other measures such as the institution of a household credit registry. The ban on consumer lending (except for mortgages) was adopted to limit household indebtedness, a small part of total bank lending. Support of other types of lending such as mortgages and SMEs financing should help boosting banking activities.

\section{The authorities underlined the importance of the measures to improve banking supervision. They considered that improved transparency and financial reporting of banking institutions would allow a more prospective risk management. The authorities plan to continue implementing new measures by creating a financial reporting tool and adopting an accounting plan based on IAS/IFS.}

\section{Staff appraisal:}

The authorities should speed up financial sector reform to strengthen and improve the efficiency of financial institutions. In particular, recommendations of the 2007 FSAP Update of the financial sector should be implemented forcefully, seeking to clarify the role of public banks and strengthen their governance, further improve the operational environment, and encourage nonbank financing. The ongoing efforts to reduce NPLs should continue, to bring their levels closer to comparable countries. Authorities should monitor closely the effects of the new measures for improving bank lending to ensure that they do not undermine long-term bank solvency. The ban on consumer lending (except for mortgages) is a potential hurdle to financial sector development, and could be removed when the household credit registry will be operational and allow a better assessment of households' indebtedness. Incentives for mortgages and SMEs financing should not weaken credit risk assessment. Possibilities for resuming the privatization process of major public banks suspended two years ago should be explored, without ruling out exempting the financial sector from the new restrictions on FDI. 


\section{Slow Progress in Structural Reforms Will Weigh on Future Growth}

\section{Background and Staff Analysis}

28. Algeria's measures to boost domestic private investment could hamper much needed foreign direct investment (FDI). The authorities established for new FDI a 49 percent ceiling for foreign stakeholding, forcing association with domestic partners as majority stakeholders (Box 3). Although management of the project by the foreign partner is allowed, this may deter those seeking a majority interest in the project.

29. The surge in imports over the past few years illustrates Algeria's growing openness, but trade with Maghreb partners remains marginal. Algeria played an active role in the Maghreb regional initiative that started in 2004, and the integration to the Arab Free Trade Zone in early 2009 is increasing trade with Arab partners. Negotiations for WTO entry are continuing. On the other hand, benefits from the $2005 \mathrm{EU}$ Association Agreement appear limited so far, notably concerning the development of $\mathrm{NH}$ exports.

\section{Authorities' Views and Policy Intentions}

30. The authorities are concerned about Algeria's relative international business climate rankings but stressed that measures were aimed to boost private investment. In particular, enhanced infrastructures will be key in creating new investment opportunities. Streamlining of customs processes should also facilitate trade. The authorities insisted that the new FDI restrictions were tailored to allow foreign investors to retain management of the project despite their minority stake. They view the 49 percent participation as intended to bring more domestic investors to foreign-sponsored projects. Moreover, the authorities welcomed staff's analysis on successful export diversification strategies in Chile and Malaysia, and will explore possible lessons for Algeria.

31. The authorities emphasized their commitment to promote regional and multilateral trade but recognized difficulties in trade negotiations. 


\section{Staff appraisal:}

Staff urges the authorities to accelerate structural reforms to improve the business climate. Staff commends the authorities for the efforts to improve infrastructure to boost NH growth but stresses that these efforts are not sufficient to improve investment climate.

Staff considers that some measures adopted in the 2009 Supplementary Budget Law and the slow pace of trade liberalization could be detrimental to the diversification of the economy. The new regulations for FDI projects could deter foreign investor to open subsidiaries in Algeria, preventing much needed technology transfer. In staff's view, the diversification strategy should strike a right balance between domestic and foreign investment and financing.

Staff encourages the authorities to pursue their efforts to seek greater benefit from the Association Agreement with the EU and to join the WTO, and expedite Algeria's participation as a creditor in the Enhanced HIPC Initiative.

\section{Box 3. Relevant Measures Adopted by the 2009 Supplementary Budget Law (2009 SBL)}

1. Reform of foreign direct investment (FDI) regime: (a) for all new FDI, the majority stake (51 percent) must belong to a domestic partner(s); (b) all new investments require the approval of the national council of investments; and (c) the government and public enterprises have a preemptive purchase right for all sales by or to foreign investors.

2. New consumer lending rules: all consumers lending is banned, except for mortgages.

3. Promotion of domestic investment: (a) new tax deductions for leasing purchases

(i.e. "credit bail"); (b) the National investment fund is provided with a capital of

150 billion DA; (c) new cap for government guaranties to SMEs loans increased from 50 million DA to 250 million DA; and (d) creation of a 48 billion DA public investment fund to invest in SMEs created by young entrepreneurs.

4. Support to domestic financial markets development: (a) tax incentives on public debt transactions and stocks; (b) all new FDI projects should seek additional financing through domestic financial institutions; and (c) banks are authorized to lend up to 25 percent of their equity to a business in which they hold an equity interest.

5. External trade operations: (a) all import operations must be only paid through a letter of credit (i.e. "crédit documentaire"); and (b) mandatory tax identification number for foreign trade operations.

6. Promotion of the real estate market: (a) tax exemptions to homeowners renting to low income families; (b) mortgages to public servants granted at subsidized interest rates (one percent); and (c) subsidies (down payment and interests) to low income households for housing acquisition. 
Panel B. Algeria: International Comparisons

Credit growth has been robust during the last five years

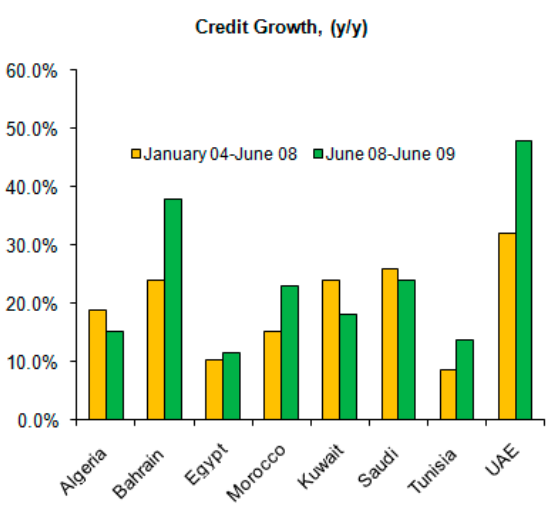

Non Oil revenues has been growing and is one of the highest among oil producers

Non-Oil Revenuee, in Percent of Non-oil GDP

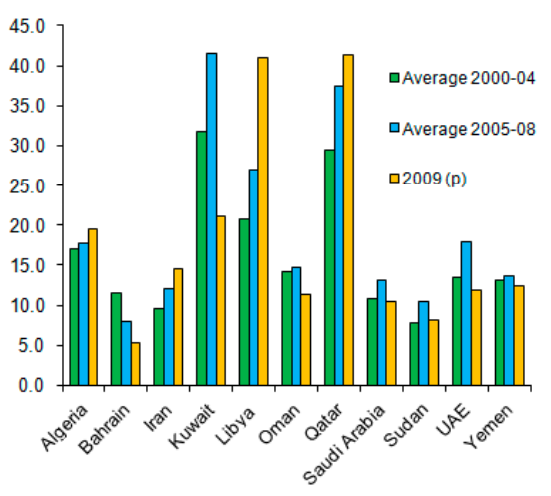

FDI in Algeria has been low and new measures in SBL could further deter foreign investors.

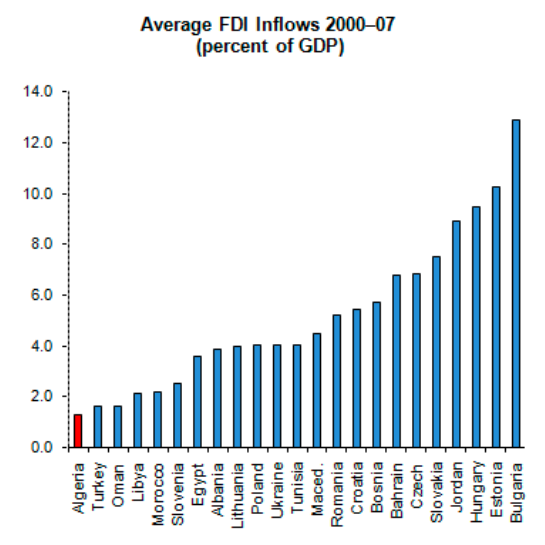

But intermidiation remains low compared to regional partners...

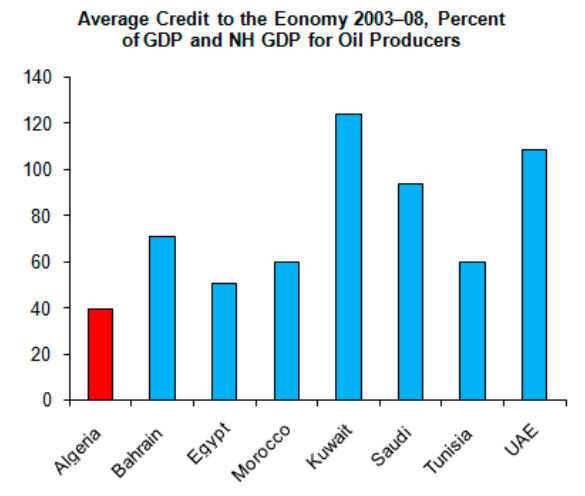

Non Oil fiscal deficit is close to the average of regional oil procucers

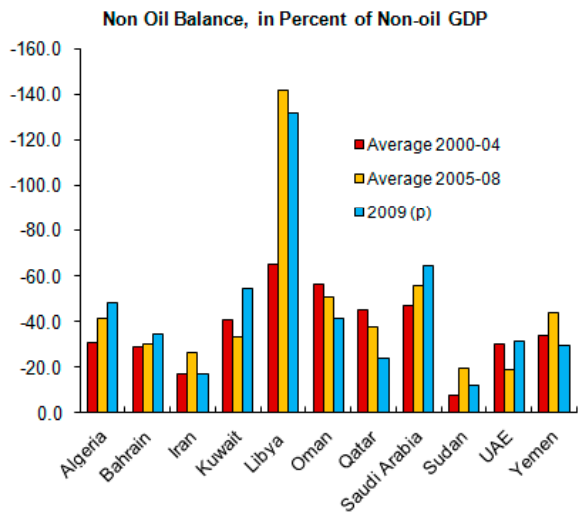

Algeria ranks low in international business climate rakings (137 out of 183 countries in 2010 DB)

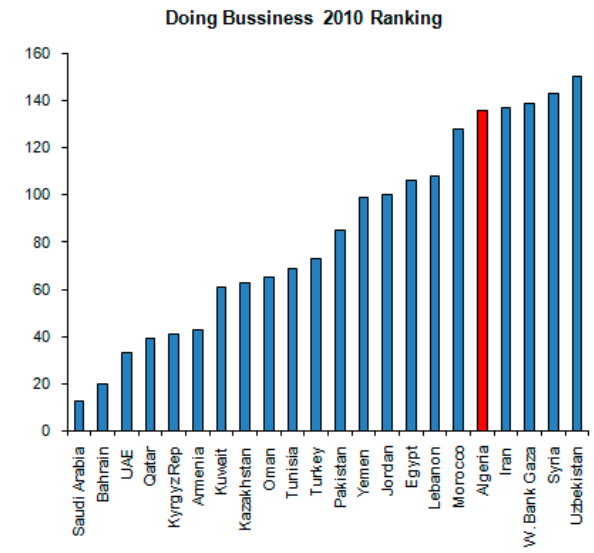

Source: Algerian authorities; and IMF staff estimates. 
Table 1. Algeria: Selected Economic and Financial Indicators, 2006-14

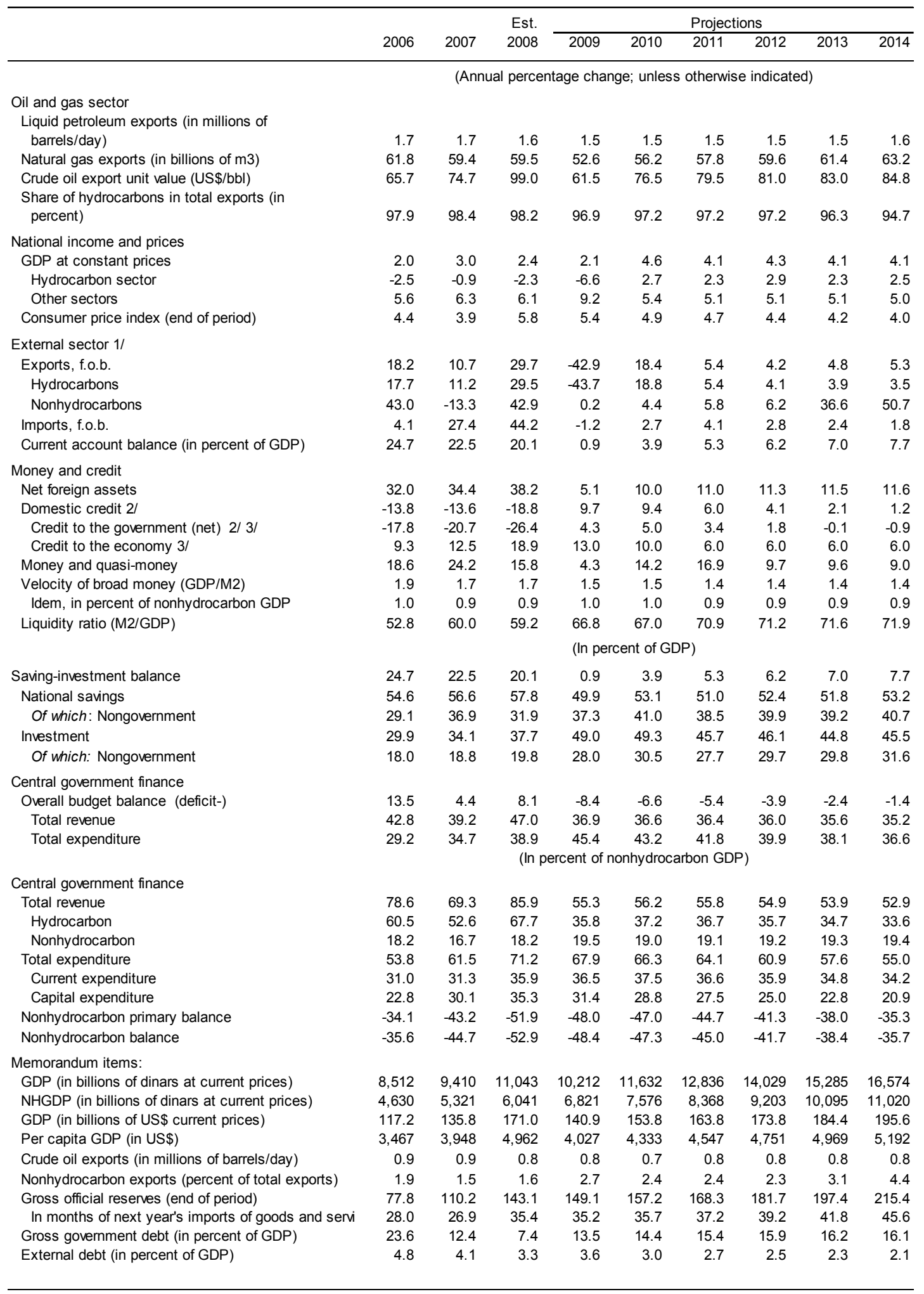

Sources: Algerian authorities; and Fund staff estimates and projections.

1/ In U.S. dollars terms.

2/ In percent of beginning money stock.

3/ Including the impact of the financial restructuring in 2006 involving the swap of government bonds for bank claims on public enterprises. 
Table 2. Algeria: Balance of Payments, 2006-14

\begin{tabular}{|c|c|c|c|c|c|c|c|c|c|}
\hline & & & & & & Project & & & \\
\hline & 2006 & 2007 & $2008^{-}$ & 2009 & 2010 & 2011 & 2012 & 2013 & 2014 \\
\hline & & (In billi & f U.S. d & lars; unl & s otherv & se indic & ted) & & \\
\hline Current account & 29.0 & 30.6 & 34.5 & 1.3 & 6.0 & 8.7 & 10.8 & 12.9 & 15.1 \\
\hline Trade balance & 34.1 & 34.2 & 40.6 & 7.3 & 14.5 & 15.8 & 17.1 & 18.9 & 21.3 \\
\hline Exports, f.o.b. & 54.7 & 60.6 & 78.6 & 44.9 & 53.1 & 56.0 & 58.3 & 61.1 & 64.3 \\
\hline Hydrocarbons & 53.6 & 59.6 & 77.2 & 43.4 & 51.6 & 54.4 & 56.7 & 58.9 & 60.9 \\
\hline Volume change (in percent) & -2.8 & -1.6 & -3.3 & -10.2 & 1.9 & 1.4 & 2.2 & 1.4 & 1.4 \\
\hline Price change (in percent) & 21.0 & 12.9 & 34.1 & -37.3 & 16.8 & 3.9 & 1.9 & 2.5 & 2.1 \\
\hline Other & 1.1 & 1.0 & 1.4 & 1.4 & 1.5 & 1.6 & 1.6 & 2.2 & 3.4 \\
\hline Imports, f.o.b. & -20.7 & -26.4 & -38.0 & -37.5 & -38.6 & -40.1 & -41.2 & -42.2 & -43.0 \\
\hline Volume change (in percent) & -5.7 & 13.7 & 31.7 & 17.2 & 0.8 & 1.6 & 0.9 & 0.5 & 0.1 \\
\hline Price change (in percent) & 10.4 & 12.0 & 9.5 & -15.7 & 1.9 & 2.4 & 1.9 & 1.9 & 1.7 \\
\hline Services and income (net) & -6.7 & -5.9 & -8.9 & -9.0 & -11.6 & -10.3 & -9.4 & -9.2 & -9.6 \\
\hline Services (net) & -2.2 & -4.0 & -7.6 & -8.0 & -8.9 & -9.3 & -9.5 & -9.7 & -9.7 \\
\hline Credit & 2.6 & 2.9 & 3.5 & 3.0 & 3.3 & 3.5 & 3.6 & 3.8 & 3.9 \\
\hline Debit & -4.8 & -6.9 & -11.1 & -10.9 & -12.2 & -12.7 & -13.1 & -13.4 & -13.7 \\
\hline Income (net) & -4.5 & -1.8 & -1.3 & -1.0 & -2.7 & -1.0 & 0.1 & 0.5 & 0.2 \\
\hline Credit & 2.4 & 3.8 & 5.1 & 3.9 & 3.7 & 6.2 & 8.2 & 8.8 & 8.8 \\
\hline Debit & -6.9 & -5.6 & -6.5 & -5.0 & -6.3 & -7.2 & -8.1 & -8.4 & -8.7 \\
\hline Interest payments & -0.8 & -0.2 & -0.2 & -0.2 & -0.2 & -0.2 & -0.1 & -0.1 & -0.1 \\
\hline Other, including profit repatriation & -6.2 & -5.4 & -6.3 & -4.8 & -6.2 & -7.1 & -7.9 & -8.2 & -8.5 \\
\hline Transfers (net) & 1.6 & 2.2 & 2.8 & 3.0 & 3.0 & 3.1 & 3.2 & 3.2 & 3.3 \\
\hline Capital account & -11.2 & -1.1 & 2.5 & 2.1 & 2.4 & 2.9 & 3.3 & 3.7 & 4.1 \\
\hline Medium- and long-term capital & -10.1 & 0.6 & 1.9 & 1.5 & 1.8 & 2.3 & 2.6 & 3.0 & 3.4 \\
\hline Direct investment (net) & 1.8 & 1.4 & 2.3 & 2.0 & 2.2 & 2.4 & 2.8 & 3.1 & 3.5 \\
\hline Loans (net) & -11.9 & -0.8 & -0.4 & -0.5 & -0.4 & -0.2 & -0.1 & -0.1 & -0.1 \\
\hline Drawings & 1.0 & 0.5 & 0.8 & 0.8 & 0.7 & 0.8 & 0.8 & 0.8 & 0.8 \\
\hline Amortization & -12.9 & -1.3 & -1.3 & -1.3 & -1.1 & -1.0 & -0.9 & -0.9 & -0.9 \\
\hline $\begin{array}{l}\text { Short-term capital and errors and } \\
\text { omissions }\end{array}$ & -1.1 & -1.7 & 0.6 & 0.6 & 0.6 & 0.6 & 0.6 & 0.6 & 0.6 \\
\hline Overall balance & 17.7 & 29.6 & 37.0 & 3.4 & 8.4 & 11.6 & 14.1 & 16.6 & 19.1 \\
\hline Financing & -17.7 & -29.6 & -37.0 & -3.4 & -8.4 & -11.6 & -14.1 & -16.6 & -19.1 \\
\hline Official reserves (increases -) & -17.7 & -29.6 & -37.0 & -3.4 & -8.4 & -11.6 & -14.1 & -16.6 & -19.1 \\
\hline Memorandum items: & & & & & & & & & \\
\hline Current account balance (in percent of & & & & & & & & & \\
\hline GDP) & 24.7 & 22.5 & 20.1 & 0.9 & 3.9 & 5.3 & 6.2 & 7.0 & 7.7 \\
\hline Algerian crude oil price (US\$/barrel) 1/ & 65.7 & 74.7 & 99.0 & 61.5 & 76.5 & 79.5 & 81.0 & 83.0 & 84.8 \\
\hline Gross official reserves (in billions of US\$) & 77.8 & 110.2 & 143.1 & 149.1 & 157.2 & 168.3 & 181.7 & 197.4 & 215.4 \\
\hline Idem, in months of next year's imports & 28.0 & 26.9 & 35.4 & 35.2 & 35.7 & 37.2 & 39.2 & 41.8 & 45.6 \\
\hline Gross external debt (in billions of US\$) & 5.6 & 5.6 & 5.6 & 5.1 & 4.6 & 4.4 & 4.3 & 4.3 & 4.2 \\
\hline Of which: Short term & 0.6 & 0.7 & 1.3 & $\ldots$ & $\ldots$ & $\ldots$ & $\ldots$ & $\ldots$ & $\ldots$ \\
\hline External debt/exports (in percent) & 9.8 & 8.8 & 6.8 & 10.6 & 8.2 & 7.5 & 7.0 & 6.6 & 6.1 \\
\hline External debt/GDP (in percent) & 4.8 & 4.1 & 3.3 & 3.6 & 3.0 & 2.7 & 2.5 & 2.3 & 2.1 \\
\hline
\end{tabular}

Sources: Algerian authorities; and Fund staff estimates and projections.

$1 /$ Weighted average of quarterly data.

2/ Including SDR allocation 
Table 3. Algeria: Summary of Central Government Operations, 2006-14 1/

\begin{tabular}{|c|c|c|c|c|c|c|c|c|c|}
\hline & & & & Est. & & & ojections & & \\
\hline & 2006 & 2007 & 2008 & 2009 & 2010 & 2011 & 2012 & 2013 & 2014 \\
\hline & & & & In billions & of Algeriar & dinars) & & & \\
\hline Budget revenue and grants & 3,640 & 3,688 & 5,191 & 3,772 & 4,255 & 4,669 & 5,054 & 5,443 & 5,833 \\
\hline Hydrocarbon revenue $2 /$ & 2,799 & 2,797 & 4,089 & 2,443 & 2,817 & 3,069 & 3,287 & 3,499 & 3,698 \\
\hline Nonhydrocarbon revenue & 841 & 891 & 1,102 & 1,329 & 1,437 & 1,599 & 1,767 & 1,944 & 2,134 \\
\hline Tax revenue & 721 & 767 & 965 & 1,194 & 1,342 & 1,489 & 1,647 & 1,812 & 1,997 \\
\hline Nontax revenues & 120 & 124 & 137 & 135 & 95 & 110 & 120 & 132 & 137 \\
\hline Grants & 0 & 0 & 0 & 1 & 1 & 1 & 1 & 1 & 0 \\
\hline Total expenditure & 2,453 & 3,110 & 4,144 & 4,600 & 5,022 & 5,367 & 5,604 & 5,816 & 6,065 \\
\hline Current expenditure & 1,434 & 1,667 & 2,166 & 2,487 & 2,838 & 3,063 & 3,300 & 3,517 & 3,766 \\
\hline Personnel expenditure & 531 & 629 & 827 & 876 & 969 & 1,031 & 1,095 & 1,162 & 1,229 \\
\hline Mudjahidins' pensions & 93 & 102 & 103 & 109 & 109 & 109 & 109 & 109 & 109 \\
\hline Material and supplies & 96 & 94 & 112 & 132 & 158 & 166 & 173 & 181 & 188 \\
\hline Current transfers & 646 & 763 & 1,066 & 1,343 & 1,575 & 1,728 & 1,889 & 2,028 & 2,202 \\
\hline Interest payments & 69 & 80 & 59 & 27 & 26 & 30 & 34 & 37 & 37 \\
\hline Capital expenditure & 1,019 & 1,442 & 1,977 & 2,113 & 2,184 & 2,304 & 2,304 & 2,299 & 2,299 \\
\hline Budget balance & 1,187 & 578 & 1,047 & -828 & -767 & -699 & -549 & -373 & -232 \\
\hline Special accounts & -4 & -19 & -31 & -11 & 0 & 0 & 0 & 0 & 0 \\
\hline Net lending by the treasury & 32 & 141 & 124 & 21 & 0 & 0 & 0 & 0 & 0 \\
\hline Budget balance excluding & & & & & & & & & \\
\hline Rehabilitation fund & 1,151 & 418 & 892 & -860 & -767 & -699 & -549 & -373 & -232 \\
\hline Nonhydrocarbon primary balance & $-1,580$ & $-2,298$ & $-3,137$ & $-3,276$ & $-3,558$ & $-3,738$ & $-3,803$ & $-3,835$ & $-3,894$ \\
\hline Primary balance & 1,219 & 498 & 951 & -834 & -741 & -669 & -516 & -336 & -196 \\
\hline Nonhydrocarbon balance & $-1,648$ & $-2,379$ & $-3,196$ & $-3,303$ & $-3,584$ & $-3,768$ & $-3,836$ & $-3,872$ & $-3,931$ \\
\hline Overall balance & 1,151 & 418 & 892 & -860 & -767 & -699 & -549 & -373 & -232 \\
\hline Financing & $-1,151$ & -418 & -892 & 860 & 767 & 699 & 549 & 373 & 232 \\
\hline Domestic & -992 & -307 & -869 & 882 & 790 & 713 & 564 & 387 & 247 \\
\hline Bank & $-1,165$ & -521 & $-1,026$ & 282 & 340 & 263 & 164 & -13 & -103 \\
\hline Nonbank & 173 & 214 & 157 & 600 & 450 & 450 & 400 & 400 & 350 \\
\hline Foreign & -159 & -111 & -23 & -22 & -22 & -15 & -14 & -14 & -14 \\
\hline & & & & (In pe & cent of G & & & & \\
\hline Total revenue & 42.8 & 39.2 & 47.0 & 36.9 & 36.6 & 36.4 & 36.0 & 35.6 & 35.2 \\
\hline Total expenditure & 29.2 & 34.7 & 38.9 & 45.4 & 43.2 & 41.8 & 39.9 & 38.1 & 36.6 \\
\hline Current expenditure & 16.8 & 17.7 & 19.6 & 24.4 & 24.4 & 23.9 & 23.5 & 23.0 & 22.7 \\
\hline Capital expenditure & 12.4 & 17.0 & 19.3 & 21.0 & 18.8 & 17.9 & 16.4 & 15.0 & 13.9 \\
\hline Overall balance & 13.5 & 4.4 & 8.1 & -8.4 & -6.6 & -5.4 & -3.9 & -2.4 & -1.4 \\
\hline & & & & ercent of & nonhydroc & irbon GDF & & & \\
\hline Total revenue & 78.6 & 69.3 & 85.9 & 55.3 & 56.2 & 55.8 & 54.9 & 53.9 & 52.9 \\
\hline Hydrocarbon revenue & 60.5 & 52.6 & 67.7 & 35.8 & 37.2 & 36.7 & 35.7 & 34.7 & 33.6 \\
\hline Nonhydrocarbon revenue & 18.2 & 16.7 & 18.2 & 19.5 & 19.0 & 19.1 & 19.2 & 19.3 & 19.4 \\
\hline Of which: Tax revenue & 15.6 & 14.4 & 16.0 & 17.5 & 17.7 & 17.8 & 17.9 & 17.9 & 18.1 \\
\hline Total expenditure & 53.8 & 61.5 & 71.2 & 67.9 & 66.3 & 64.1 & 60.9 & 57.6 & 55.0 \\
\hline Current expenditure & 31.0 & 31.3 & 35.9 & 36.5 & 37.5 & 36.6 & 35.9 & 34.8 & 34.2 \\
\hline Of which: Personnel expenditure & 11.5 & 11.8 & 13.7 & 12.8 & 12.8 & 12.3 & 11.9 & 11.5 & 11.2 \\
\hline Capital expenditure & 22.0 & 27.1 & 32.7 & 31.0 & 28.8 & 27.5 & 25.0 & 22.8 & 20.9 \\
\hline Nonhydrocarbon primary balance & -34.1 & -43.2 & -51.9 & -48.0 & -47.0 & -44.7 & -41.3 & -38.0 & -35.3 \\
\hline Nonhydrocarbon overall balance & -35.6 & -44.7 & -52.9 & -48.4 & -47.3 & -45.0 & -41.7 & -38.4 & -35.7 \\
\hline Oil stabilization fund (in billions of Algerian dinars) & 2931.1 & 3215.5 & 4280.0 & 3998.3 & 3658.7 & 3395.4 & 3231.7 & 3244.5 & 3347.7 \\
\hline
\end{tabular}

Sources: Algerian authorities; and Fund staff estimates and projections.

$1 /$ On cash basis.

2/ Including dividends of Sonatrach. 
Table 4. Algeria: Monetary Survey, 2006-10

\begin{tabular}{|c|c|c|c|c|c|}
\hline & \multirow[b]{2}{*}{2006} & \multirow[b]{2}{*}{2007} & \multirow[b]{2}{*}{2008} & \multicolumn{2}{|c|}{ Projections } \\
\hline & & & & 2009 & 2010 \\
\hline & \multicolumn{5}{|c|}{ (In billions of Algerian dinars; at end of period) } \\
\hline Net foreign assets & 5,515 & 7,416 & 10,247 & 10,770 & 11,842 \\
\hline Of which: Bank of Algeria & 5,526 & 7,383 & 10,227 & 10,765 & 11,836 \\
\hline Net domestic assets & -687 & $-1,767$ & $-3,707$ & $-3,950$ & $-4,053$ \\
\hline Domestic credit & 602 & -340 & $-1,402$ & -771 & -128 \\
\hline Credit to government (net) $1 / 2 /$ & $-1,304$ & $-2,602$ & $-4,092$ & $-3,810$ & $-3,470$ \\
\hline Credit to the economy $1 /$ & 1,905 & 2,262 & 2,689 & 3,039 & 3,343 \\
\hline Of which: Private sector & 1,056 & 1,215 & 1,413 & 1,597 & 1,757 \\
\hline Other items net & $-1,289$ & $-1,427$ & $-2,305$ & $-3,179$ & $-3,925$ \\
\hline Money and quasi-money (M2) & 4,828 & 5,648 & 6,540 & 6,820 & 7,789 \\
\hline Excluding Sonatrach deposits & 4,098 & 4,386 & 5,238 & 5,919 & 6,689 \\
\hline Money & 3,178 & 3,887 & 4,549 & 5,209 & 5,886 \\
\hline \multirow[t]{2}{*}{ Quasi-money } & 1,650 & 1,761 & 1,991 & 1,611 & 1,903 \\
\hline & \multicolumn{5}{|c|}{ (Percent change over 12-month period) } \\
\hline Money and quasi-money (M2) & 18.6 & 17.0 & 15.8 & 4.3 & 14.2 \\
\hline Excluding Sonatrach deposits & 14.7 & 7.0 & 19.4 & 13.0 & 13.0 \\
\hline Credit to the economy $1 /$ & 7.1 & 18.7 & 18.9 & 13.0 & 10.0 \\
\hline Of which: Private sector & 17.8 & 14.9 & 16.3 & 13.0 & 10.0 \\
\hline \multicolumn{6}{|l|}{ Memorandum items: } \\
\hline Liquidity ratio (e.o.p. M2/GDP) & 56.7 & 60.0 & 59.2 & 66.8 & 67.0 \\
\hline Liquidity ratio (e.o.p. M2/NHGDP) & 104.3 & 106.2 & 108.2 & 100.0 & 102.8 \\
\hline Idem, excluding deposits of Sonatrach & 88.5 & 82.4 & 86.7 & 86.8 & 88.3 \\
\hline Sonatrach deposits & 730 & 1,262 & 1,302 & 901 & 1,101 \\
\hline M2 velocity & 1.8 & 1.7 & 1.7 & 1.5 & 1.5 \\
\hline Credit to the economy/GDP & 22.4 & 24.0 & 24.4 & 29.8 & 28.7 \\
\hline Credit to the economy/NHGDP & 41.2 & 42.5 & 44.5 & 44.6 & 44.1 \\
\hline
\end{tabular}

Sources: Bank of Algeria; and Fund staff estimates and projections.

$1 /$ Includes impact of public banks' restructuring packages.

2/ Net credit to government excludes postal accounts ("dépôts CCP") at the Treasury deposited at the BA. 


\section{INTERNATIONAL MONETARY FUND}

ALGERIA

Staff Report for the 2009 Article IV Consultation Discussions-Informational Annex

Prepared by the Middle East and Central Asia Department

February 25, 20109

Contents

Page

Annexes

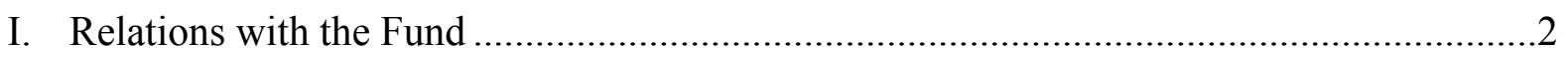

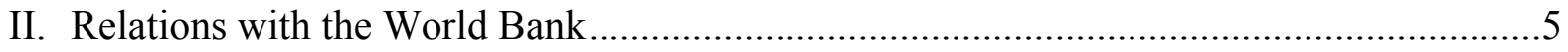

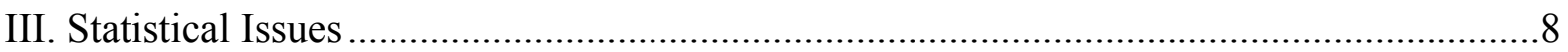


ANNEX I. RELATIONS With the FUND

(As of October 31, 2009)

\section{A. Financial Relations}

Membership Status Joined 9/26/63; Article VIII

General Resources Account

Quota

Fund holdings of currency

Reserve position in Fund

\section{SDR Department}

Net cumulative allocation

Holdings

\section{SDR Million}

$1,254.70$

$1,169.62$

85.08

SDR Million

$1,198.18$

$1,075.66$
Percent of Quota

100.00

93.22

6.78

\section{Percent of}

Allocation

100.00

89.77

Outstanding Purchases and Loans: None.

Financial Arrangements

$\begin{array}{lcccc}\text { Type } & \begin{array}{c}\text { Approval } \\ \text { Date }\end{array} & \begin{array}{c}\text { Expiration } \\ \text { Date }\end{array} & \begin{array}{c}\text { Amount } \\ \text { Approved } \\ \text { (SDR Million) }\end{array} & \begin{array}{c}\text { Amount } \\ \text { Drawn } \\ \text { (SDR Million) }\end{array} \\ \text { EFF } & 5 / 22 / 95 & 5 / 21 / 98 & 1,169.28 & 1,169.28 \\ \text { Stand-by } & 5 / 27 / 94 & 5 / 22 / 95 & 457.20 & 385.20 \\ \text { Stand-by } & 6 / 03 / 91 & 3 / 31 / 92 & 300.00 & 225.00\end{array}$

\section{Projected Obligations to Fund}

(SDR million; based on existing use of resources and present holdings of SDRs)

\begin{tabular}{lcccccc}
\hline & Overdue & \multicolumn{5}{c}{ Forthcoming } \\
& & 2009 & 2010 & 2011 & 2012 & 2013 \\
\hline Principal & 0.00 & 0.00 & 0.00 & 0.00 & 0.00 & 0.00 \\
Charges/interest & 0.00 & 0.08 & 0.42 & 0.42 & 0.42 & 0.42 \\
Total & 0.00 & 0.08 & 0.42 & 0.42 & 0.42 & 0.42 \\
\hline
\end{tabular}

\section{Implementation of HIPC Initiative: Not Applicable.}




\section{B. Nonfinancial Relations}

\section{Exchange Rate Arrangement}

1. From January 21, 1974 to October 1, 1994, the exchange rate of the dinar was determined on the basis of a fixed relationship with a basket of currencies, adjusted from time to time. On October 1, 1994, the Bank of Algeria introduced a managed float for the dinar through daily fixing sessions that included six commercial banks. This system has been replaced by an interbank foreign exchange market as of January 2, 1996. On December XX, 2009, the average of the buying and selling rates for the U.S. dollar was $\$ 1=$ DA 71.2, equivalent to SDR 1 = DA 109.9. No margin limits are imposed on the buying and selling exchange rates in the interbank foreign exchange market, except for a margin of DA 0.017 between the buying and selling rates of the Bank of Algeria for the dinar against the U.S. dollar.

2. The exchange regime is a managed float with no preannounced path for the exchange rate. Full surrender requirements are in effect on hydrocarbon export proceeds. Limits on the making of payments for invisible transactions and current transfers, which have remained since Algeria accepted the obligations of Article VIII, sections 2(a), 3, and 4, in 1997, are indicative according to the authorities. Inward direct investment is generally free of restrictions; controls are maintained on other capital account payments and transfers.

\section{Latest Article IV Consultation}

The discussions for the 2008 Article IV consultation with Algeria were held in Algiers during November 4-15, 2008. The staff report (IMF Country Report No. 09/108) was discussed by the Executive Board on January 21, 2009 and published on April 02, 2009.

\section{Technical Assistance}

- An MFD expert visited Algiers in January-February 2005 to advise on bank inspection.

- An STA expert visited Algiers in June-July 2005 to advise on the development of quarterly national accounts statistics.

- An MFD mission visited Algiers in July 2005 to advise on liquidity management and monetary operations.

- An MFD/LEG mission visited Algiers in July 2005 to advise on the exchange regime and the development of the foreign exchange market.

- An MFD expert visited Algiers in October 2005 to advise on foreign exchange reserve management.

- An MFD mission visited Algiers in September 2005, December 2005, and in May 2006 
to advise on bank restructuring.

- An MFD expert visited Algiers several times from February through September 2006 to assist the Bank of Algeria to develop its bank supervision and regulation capability.

- An MFD expert visited Algiers in January-February 2006 to advise on monetary and foreign exchange operations.

- An MFD expert visited Algiers in February and May 2006 to advise on foreign exchange reserve management.

- A STA mission visited Algiers in May 2006 to advise on monetary and financial statistics.

- An MFD expert visited Algiers in May 2006 to advise on payment systems.

- A STA mission visited Algiers in May 2006 to advise on consumer price statistics.

- MFDs expert visited Algiers several times from February through October 2007 to assist the Bank of Algeria in banking supervision.

- Two FAD missions visited Algiers in February 2007 to review tax policy and advise on customs administration.

- A multisector STA mission visited Algiers in February 2007 to prepare Algeria's participation in the GDDS.

- An FAD mission visited Algiers in April 2007 to continue the program of assistance in tax administration.

- An FAD mission visited Algiers in May 2008 to continue the program of assistance in tax administration.

- An MCM mission visited Algiers in May 2009 to prepare the program for harmonizing financial sector infrastructure in the Maghreb

Financial Sector Assessment Program

Algeria participated in the FSAP in 2003. The Executive Board discussed the Financial System Stability Assessment on January 14, 2004, (see IMF Country Report No. 04/138). The FSAP was updated in 2007.

\section{Resident Representative/Advisor}

None. 


\section{ANNEX II. RELATIONS WITH THE WORLD BANK}

(As of December 1, 2009)

The World Bank is preparing a new Country Partnership Strategy for Algeria, following a request for closer engagement by the Government. This is an important step after a period of low activity since the end of the previous Country Assistance Strategy in 2006. The Bank addressed several strategic objectives and development challenges through its previous CAS launched in FY2004, including: (i) building a political, social and economic environment that would enable growth, employment, social cohesion and poverty reduction; (ii) reducing the economy's high dependence on oil exports and vulnerability to oil price volatility; (iii) building a conducive investment climate to encourage private investment; and (iv) improving the effectiveness of public service delivery.

However, in 2004, as a result of the change in Government's orientation related to foreign borrowing (the Government decided against any further official foreign borrowing and, by 2006, started repaying back all its foreign obligations), no new lending activities could be engaged during the previous CAS period. The Bank's role evolved from that of financing partner to one of advisor, and, starting in 2006, the authorities expressed interest in Reimbursable Technical Assistance (RTA) from the Bank. IBRD Portfolio decreased from 11 projects (net commitment of US\$515.3 million) in FY04 to no lending after the last loan, Budget Modernizations Systems, closed in February 2009. The drastic changes altered the initial relevance and alignment of the CAS with the Country strategy, reducing the scope overall and shifting from private sector development and privatization to supporting the modernization of selected areas of state activities with AAA, RTA and a few remaining operations. Today, no Bank lending operation is under implementation, the bulk of the support is provided through RTAs and Bank-funded advisory and analytical work.

Analytical work completed over the past five years includes an update of the FSAP carried out jointly with the IMF, a Public Expenditure Review (PER) also done in collaboration with the IMF in 2006; a Labor Markets and Social Protection policy note; a second Investment Climate Assessment; and a policy note on Trade in Services. Technical assistance (TA) has supported social insurance, specifically in the area of pensions; macroeconomic modeling to the Ministry of Finance and the Central Bank; improvement of the doing business indicators; training in analytical tools for poverty, governance and private sector development issues with the Conseil National Economique et Social (CNES); training in rural development topics; training in skills development and technical, vocational and educational. RTA activities have been agreed and implemented in the water sector, with the Ministry of Urban Planning and Environment (MATET) in the area of solid waste management and the rehabilitation of open dumps and the clean development mechanism; advisory services on procurement to SONATRACH; two technical assistance activities were completed recently: preparation of management contracts in water supply for three of the largest cities; and capacity building for the Caisse Nationale d'Equipement et de Développement (CNED); and 
assistance to the Central Bank for the creation of a credit bureau and on the regulatory framework of credit cooperatives. The World Bank Treasury has an ongoing Reserves Advisory management Program with Banque d'Algérie.

The new CPS is scheduled for delivery in FY10, covering FY10-13. The thrust of the CPS remains that of supporting the country towards a transition to a new, sustainable growth model and economic diversification. The CPS program is under discussion with the Authorities, and it is expected that it will be organized around the following three pillars:

1. Economic diversification and support to economic growth, to include strategic support on economic diversification, pilot centers for competitiveness, agriculture and rural development, ecotourism, strengthening of the Central Bank functions, support to the Ministry of Finance on governance of public banks; and support to the Telecom regulator.

2. Support to the development and implementation of economic policies and their evaluation. This covers important work on impact evaluation of public policies and analysis of key products subsidies; technical assistance for preparation of the new household survey; and

3. Sustainable Development, including improvement in solid waste management and the study with the Ministry of energy. The specific activities under each of this pillar can change and remain to be defined in later years of the CPS.

The main instruments of cooperation under the new CAS will remain that of reimbursable technical assistance, and will be complemented by the use of trust funds to selectively support TA or studies, and of Bank budget to support the identification of RTAs, policy dialogues in the priority areas, and technical assistance for capacity building. 


\section{Algeria: Financial Relations with the World Bank}

(As of December 1, 2009)

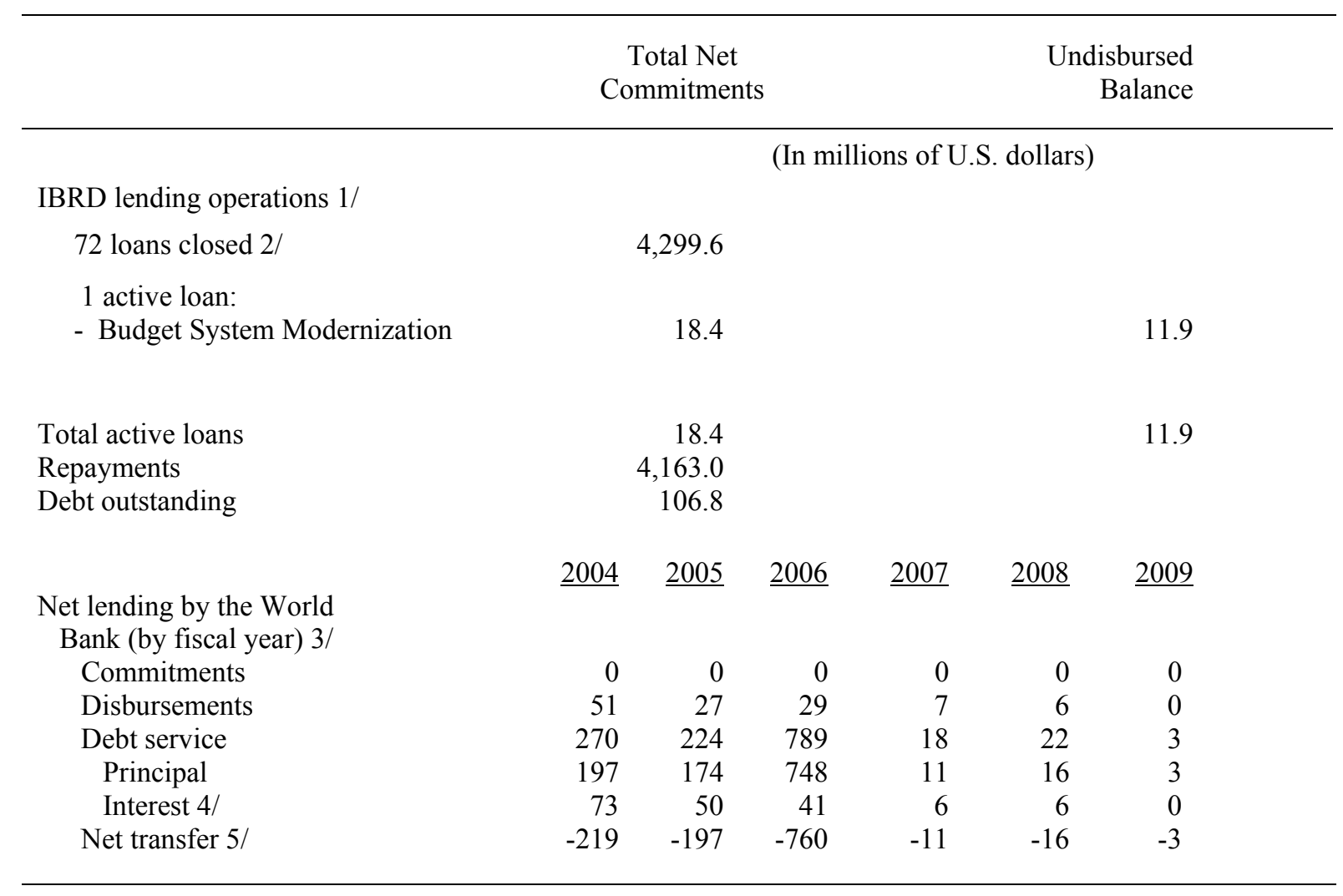

1/ IDA has no operations in Algeria.

2/ Less cancellations, includes adjustment lending.

3/ Fiscal years start July 1 and end June 30.

4/ Includes charges.

5/ Equal to disbursements minus debt service. 
Algeria—Statistical Issues Appendix

\section{Assessment of Data Adequacy for Surveillance}

General: Data provision has some shortcomings, but is broadly adequate for surveillance. Government finance statistics, national accounts, and prices have several shortcomings that hamper analysis.

National Accounts: Key shortcomings in national accounts include an outdated base year for constant price GDP estimates, long lags for publication of data, and incomplete application of the 1993 System of National Accounts. STA has recommended giving priority to compiling GDP at constant prices (including quarterly accounts) and to rebasing the GDP series.

Price Statistics: Data are published with a delay of about 3 months.

Government finance statistics: Key shortcomings include insufficient institutional coverage (coverage is limited to Budgetary Central Government, albeit in a wide sense, including the general budget, the annexed budget, and the special treasury accounts), classification problems, long lags for production of statistics, and lack of reconciliation of financing with the monetary accounts. Key factors behind these weaknesses include the lack of financial resources allocated to the compilation of statistics, insufficient interagency coordination, as well as concerns about accuracy that give rise to reluctance to publish provisional data.

Monetary statistics: The authorities need to ensure the data consistency with the methodology in the Monetary and Financial Statistics Manuel, 2000. Timely reporting of balance sheet data by some state-owned commercial banks remains problematic, and most commercial banks do not report all data needed to compile the monetary survey. Prudential data reported by state-owned banks are unreliable and not timely.

Balance of payments: Although balance of payments statistics are generally of good quality, they could benefit from a survey for direct investment data.

\section{Data Standards and Quality}

Algeria began participation in the General $\quad$ No data ROSC is available.

Data Dissemination System (GDDS) on

April 21, 2009. 
Algeria: TAble of Common Indicators REQuired FOR SURVEILlance

As of December 7, 2009

\begin{tabular}{|c|c|c|c|c|c|}
\hline & $\begin{array}{c}\text { Date of latest } \\
\text { observation }\end{array}$ & $\begin{array}{l}\text { Date } \\
\text { received }\end{array}$ & $\begin{array}{c}\text { Frequency of } \\
\text { Data }^{7}\end{array}$ & $\begin{array}{l}\text { Frequency of } \\
\text { Reporting }\end{array}$ & $\begin{array}{l}\text { Frequency of } \\
\text { publication }^{7}\end{array}$ \\
\hline Exchange Rates & $10 / 09$ & $11 / 03 / 09$ & $\mathrm{D}$ & M & $\mathrm{W}$ \\
\hline International Reserve Assets and Reserve Liabilities of the Monetary Authorities ${ }^{1}$ & 09/09 & $11 / 21 / 09$ & $\mathrm{D}$ & M & $\mathrm{M}$ \\
\hline Reserve/Base Money & $06 / 09$ & $10 / 21 / 09$ & M & M & M \\
\hline Broad Money & $06 / 09$ & $11 / 21 / 09$ & M & M & M \\
\hline Central Bank Balance Sheet & $06 / 09$ & $10 / 21 / 09$ & M & M & A \\
\hline Consolidated Balance Sheet of the Banking System & $06 / 09$ & $10 / 21 / 09$ & M & M & A \\
\hline Interest Rates ${ }^{2}$ & $08 / 09$ & $10 / 21 / 09$ & M & M & M \\
\hline Consumer Price Index & $09 / 09$ & $11 / 31 / 09$ & M & M & M \\
\hline Revenue, Expenditure, Balance and Composition of Financing ${ }^{3}-$ General Government ${ }^{4}$ & $\cdots$ & $\cdots$ & NA & NA & NA \\
\hline Revenue, Expenditure, Balance and Composition of Financing ${ }^{3}-$ Central Government & $06 / 09$ & $11 / 03 / 09$ & Q & I & A \\
\hline Stocks of Central Government and Central Government-Guaranteed Debt ${ }^{5}$ & $06 / 09$ & $11 / 03 / 09$ & Q & I & A \\
\hline External Current Account Balance & $06 / 09$ & $11 / 03 / 09$ & $\mathrm{Q}$ & Q & A \\
\hline Exports and Imports of Goods and Services & $09 / 07$ & $11 / 05 / 07$ & Q & Q & A \\
\hline GDP/GNP & 2008 & $10 / 31 / 09$ & A & A & A \\
\hline Gross External Debt & $09 / 07$ & $11 / 05 / 07$ & A & A & A \\
\hline International Investment Position ${ }^{6}$ & $\ldots$ & $\ldots$ & $\mathrm{PA}$ & $\mathrm{PA}$ & PA \\
\hline
\end{tabular}

${ }^{1}$ Any reserve assets that are pledged of otherwise encumbered should be specified separately. Also, data should comprise short-term liabilities linked to a foreign currency but settled by other means as well as the notional values of financial derivatives to pay and to receive foreign currency, including those linked to a foreign currency but settled by other means.

${ }^{2}$ Both market-based and officially determined, including discount rates, money market rates, rates on treasury bills, notes and bonds.

${ }^{3}$ Foreign, domestic bank, and domestic nonbank financing

${ }^{4}$ The general government consists of the central government (budgetary funds, extra budgetary funds, and social security funds) and state and local governments.

${ }^{5}$ Including currency and maturity composition.

${ }^{6}$ Includes external gross financial asset and liability positions vis-à-vis nonresidents. Data are partial, because of shortcomings in the compilation of FDI. 


\section{INTERNATIONAL MONETARY FUND}

\section{Public Information Notice}

Draft Public Information Notice (PIN) No. 10/29

FOR IMMEDIATE RELEASE

February 23, 2010
International Monetary Fund

$70019^{\text {th }}$ Street, NW

Washington, D. C. 20431 USA

\section{IMF Executive Board Concludes 2009 Article IV Consultation with Algeria}

On January 8, 2010, the Executive Board of the International Monetary Fund (IMF) concluded the Article IV consultation with Algeria on a lapse of time basis. ${ }^{1}$

\section{Background}

Algeria has enjoyed several years of strong economic performance driven by public spending, but continues to face important challenges. Nonhydrocarbon growth has been robust, inflation low and the government has accumulated large savings in the oil stabilization fund (FRR) to finance a sizeable public investment program (PIP) while reducing public and external debts to very low levels. However, the fall of global demand for hydrocarbons has exposed Algeria's vulnerabilities. Despite the recent recovery of oil prices and the improvement of medium-term financial perspectives, the economy remains too dependent on hydrocarbon exports, unemployment, although declining, is still relatively high, and productivity and the business climate lag behind main trading partners. Nonhydrocarbon growth and job creation are largely sustained by public spending, highlighting the pressing need to accelerate structural reforms to diversify the economy and let a competitive and outward-oriented private sector emerge.

\footnotetext{
${ }^{1}$ Under Article IV of the IMF's Articles of Agreement, the IMF holds bilateral discussions with members, usually every year. A staff team visits the country, collects economic and financial information, and discusses with officials the country's economic developments and policies. On return to headquarters, the staff prepares a report, which forms the basis for discussion by the Executive Board. At the conclusion of the discussion, the Managing Director, as Chairman of the Board, summarizes the views of Executive Directors, and this summary is transmitted to the country's authorities. This year's Article IV consultation was concluded on a lapse of time basis. Under the IMF's lapse of time procedures, the Executive Board completes Article IV consultations without convening formal discussions.
} 
Algeria has faced the global slowdown from a position of relative strength. Growth in the nonhydrocarbon sector will likely reach 9 percent in 2009, reflecting an excellent cereal harvest and the continued strength of PIP-led service and construction sectors. Hydrocarbon production will decline further this year (by 6-7 percent) due to lower global demand, bringing overall growth down to about 2 percent. Headline inflation reached 5.8 percent $(y-0-y)$ in September 2009 due to a 25 percent surge in fresh food prices, reportedly caused by structural shortcomings in the supply chain. With a small current account surplus, official reserves have grown by $\$ 3$ billion since end-2008, reaching $\$ 146$ billion at end-September 2009 (3 years of imports). Following the fall in hydrocarbon revenues, Algeria will post a fiscal deficit of 8 percent of GDP in 2009, following a surplus of 8 percent in 2008 . This deficit should be largely financed with domestic nonbank resources. The real effective exchange rate continued to be close to its equilibrium level.

The outlook remains favorable in the short term, but is sensitive in the medium term to future levels of oil prices. Growth will continue to be sustained in the short term by large public spending and the acceleration of the national hydrocarbon company's investment program. Nonhydrocarbon GDP could grow by $5 \frac{1}{2}$ percent in 2010 , and hydrocarbon output should improve with the international recovery, contributing to overall growth of around $4 \frac{1}{2}$ percent. Inflation should come below 5 percent if fresh food prices stabilize. Higher projected international oil prices would improve the external and fiscal balances, but these would remain well below the large surpluses recorded in the past few years. A worsening world economy and a significant new decline in energy prices would present important downside risks in the medium term, as it would weaken the external and fiscal positions, force a scaling back of the PIP and other investments, and imply slower growth and higher unemployment. The medium-term outlook also rests on decisive actions to promote private sector development and economic diversification, as public spending alone cannot ensure long-term growth.

Structural reforms have been timid, and the business climate needs to be improved. The authorities have launched various initiatives aimed at increasing the banking system's lending capacity and the efficiency of public spending, including increasing the minimum capital requirement for banks, reducing the level of nonperforming loans (NPLs) through financial restructuring of public enterprises, and improving fiscal management and budget system. However, the new regulations for foreign direct investment and the slow pace of regional and multilateral trade negotiations could hamper Algeria's effort to ensure a sustainable export-oriented diversified growth. The perception of the business climate has not improved, and continues to be ranked behind those of most regional competitors.

\section{Executive Board Assessment}

Executive Directors agreed with the thrust of the staff appraisal. They welcomed Algeria's strong economic performance in recent years, with solid nonhydrocarbon growth and low inflation. In particular, they commended the authorities for prudent financial policies that have enabled a significant increase in reserves, the reduction of public and external debts to low levels, and the accumulation of large fiscal savings which will sustain the current fiscal stance in 2010. Nevertheless, they noted that the fall in oil prices and the ensuing deterioration in financial balances show that Algeria continues to face important medium-term challenges. 
Sustained efforts are needed to improve productivity, diversify the economy to reduce its high dependence on the hydrocarbon sector, and reduce high youth unemployment.

Directors supported maintaining the current fiscal stance in 2010 but encouraged the authorities to revert to a sustainable fiscal path over the medium term. They endorsed continued implementation of the PIP and support to SMEs, and noted that the sizable fiscal savings can be used to that effect. Nonetheless, Directors stressed that a thorough overhaul of the current and capital spending would free up budgetary resources, better preserve hydrocarbon wealth in the medium term and maintain fiscal space in case of adverse shock on oil prices. They welcomed the authorities' commitment to prioritize execution of the current and future PIPs based on the fiscal outlook, and advised to firmly contain current expenditure, in particular the wage bill, to make room for additional maintenance costs related to the new infrastructure. They noted that the authorities' ongoing advances to reform the revenue administration should boost further budget revenues, provided that growth in tax incentives is contained.

Directors stressed the critical importance of ensuring the quality and efficiency of public spending, which has become an important driver of Algeria's nonhydrocarbon economic growth. In that respect, they welcomed the authorities' program to modernize budget systems and the work done by the now fully operational projects evaluating agency.

Directors commended the authorities' prudent monetary policy which helped contain inflationary pressures. They noted, however, that abundant liquidity associated with the hydrocarbon sector and public spending demands continued vigilance, and that the authorities should stand ready to tighten monetary policy if inflationary pressures from excess liquidity were to materialize.

Directors considered that Algeria's exchange rate policy is consistent with medium-term external stability. They agreed with the staff's assessment that the exchange rate is broadly aligned with fundamentals. Nevertheless, Directors urged the authorities to accelerate structural reforms to improve external competitiveness. While commending the authorities' efforts to improve infrastructure, they stressed that these efforts are not sufficient to improve the investment climate. Directors noted that the new regulations for FDI projects could deter foreign investors to open subsidiaries in Algeria, preventing much needed technology transfer.

Directors encouraged the authorities to speed up financial sector reform to strengthen and improve the efficiency of financial institutions. In particular, recommendations of the 2007 FSAP Update of the financial sector could be implemented more forcefully, seeking to clarify the role of public banks and further strengthen their governance. Directors considered that possibilities for resuming the privatization process of major public banks could be explored, with the objective to increase the efficiency of the banking sector based on international best practices. They believed that ongoing efforts to reduce NPLs should continue, bringing their levels closer to those in comparable countries. Directors viewed the ban on consumer lending 
(except mortgages) as a potential hurdle to financial sector development, and suggested that it be removed once the household credit registry becomes operational.

It is expected that the next Article IV consultation with Algeria takes place on the standard 12-month cycle.

Public Information Notices (PINs) form part of the IMF's efforts to promote transparency of the IMF's views and analysis of economic developments and policies. With the consent of the country (or countries) concerned, PINs are issued after Executive Board discussions of Article IV consultations with member countries, of its surveillance of developments at the regional level, of post-program monitoring, and of ex post assessments of member countries with longer-term program engagements. PINs are also issued after Executive Board discussions of general policy matters, unless otherwise decided by the Executive Board in a particular case. 
Prel. Proj.

20052006200720082009

(Annual percentage change, unless otherwise indicated)

Domestic Economy

$\begin{array}{lrrrrr}\text { Real GDP } & 5.1 & 2.0 & 3.0 & 2.4 & 2.1 \\ \quad \text { Hydrocarbon sector } & 5.8 & -2.5 & -0.9 & -2.3 & -6.6 \\ \quad \text { Other sectors } & 4.7 & 5.6 & 6.3 & 6.1 & 9.2 \\ \text { Consumer price index (average) } & 1.6 & 2.5 & 3.9 & 5.8 & 5.4 \\ \text { Gross national savings (in percent of GDP) } & 51.8 & 54.9 & 56.6 & 57.8 & 49.9 \\ \text { Gross national investment (in percent of GDP) } & 31.2 & 29.7 & 34.1 & 37.7 & 49.0\end{array}$

External sector

(In billions of US dollars; unless otherwise indicated)

Exports, f.o.b.

$\begin{array}{lllll}46.3 & 54.7 & 60.6 & 78.2 & 44.9\end{array}$

Imports, f.o.b.

$\begin{array}{lllll}19.9 & 20.7 & 26.4 & 36.3 & 37.5\end{array}$

Current account (in percent of GDP)

$\begin{array}{lllll}20.6 & 25.2 & 22.5 & 20.2 & 0.9\end{array}$

Gross official reserves

$\begin{array}{lllll}56.2 & 77.8 & 110.2 & 143.1 & 149.1\end{array}$

Idem, in months of next year's imports

$\begin{array}{lllll}26.5 & 28.0 & 26.9 & 35.4 & 35.2\end{array}$

External debt (in percent of GDP)

$\begin{array}{lllll}16.7 & 4.8 & 4.1 & 3.3 & 3.6\end{array}$

Debt service ratio (in percent of exports)

$\begin{array}{lllll}12.5 & 23.8 & 2.4 & 1.8 & 3.0\end{array}$

Terms of trade (deterioration -) (annual percent change)

$\begin{array}{lllll}33.0 & 12.4 & 0.8 & 22.5 & -25.6\end{array}$

Real effective exchange rate (depreciation -)

(annual percent change) $1 /$

$\begin{array}{lllll}-4.0 & 0.0 & -1.1 & 3.2 & -4.3\end{array}$

Central government finance

(In percent of GDP)

Total revenue

$\begin{array}{lllll}40.9 & 43.0 & 39.2 & 47.0 & 36.9\end{array}$

Total expenditure and net lending

$\begin{array}{lllll}29.0 & 29.4 & 34.7 & 38.9 & 45.4\end{array}$

Overall budget balance (deficit-)

$\begin{array}{lllll}11.9 & 13.6 & 4.4 & 8.1 & -8.4\end{array}$

Money and credit

(Annual percentage change, unless otherwise indicated)

Net foreign assets

$\begin{array}{lllll}34.0 & 31.9 & 34.4 & 38.2 & 5.1\end{array}$

Domestic credit

$\begin{array}{lllll}-17.8 & -5.9 & -13.6 & -18.8 & 9.7\end{array}$

Credit to the government (net)

$\begin{array}{lllll}-24.4 & -8.9 & -20.7 & -26.4 & 4.3\end{array}$

Credit to the economy

$\begin{array}{rrrrr}15.9 & 7.1 & 12.5 & 18.9 & 13.0\end{array}$

Broad money

Interest rate (central bank rediscount rate, in percent)

$\begin{array}{lllll}11.1 & 18.6 & 24.2 & 15.8 & 4.3\end{array}$

$\begin{array}{lllll}4.0 & 4.0 & 4.0 & 4.0 & 4.0\end{array}$

Sources: Algerian authorities; and Fund staff estimates and projections.

1/ For 2009, as of September. 